NBER WORKING PAPER SERIES

\title{
THE IMPACT OF EXPANDING PUBLIC HEALTH INSURANCE ON SAFETY NET PROGRAM PARTICIPATION: EVIDENCE FROM THE ACA MEDICAID EXPANSION
}

\author{
Lucie Schmidt \\ Lara Shore-Sheppard \\ Tara Watson \\ Working Paper 26504 \\ http://www.nber.org/papers/w26504
NATIONAL BUREAU OF ECONOMIC RESEARCH
1050 Massachusetts Avenue \\ Cambridge, MA 02138
}

November 2019, Revised December 2021

We are grateful to the Russell Sage Foundation for financial support and to Nadine Nichols at the U.S. Department of Agriculture and to Brian Stacy at the World Bank for data. We received helpful comments from Michael Dworsky, Emily Lawler, Tom Selden, and seminar and conference participants at the American Society of Health Economics Annual Meeting, the Association for Public Policy and Management Annual Meeting, the Center for Health Economics and Policy Studies at San Diego State University, the Southern Economic Association Annual Meeting, the University at Albany, the University of Wisconsin Center for Demography and Ecology, and Williams College. Louisa Abel, Mary Beth Dato, Casey DeLano, Huy Nguyen, and Ahna Pearson provided excellent research assistance. Michael L. Anderson offered useful guidance on standard errors. The views expressed herein are those of the authors and do not necessarily reflect the views of the National Bureau of Economic Research.

NBER working papers are circulated for discussion and comment purposes. They have not been peer-reviewed or been subject to the review by the NBER Board of Directors that accompanies official NBER publications.

(C) 2019 by Lucie Schmidt, Lara Shore-Sheppard, and Tara Watson. All rights reserved. Short sections of text, not to exceed two paragraphs, may be quoted without explicit permission provided that full credit, including $\odot$ notice, is given to the source. 
The Impact of Expanding Public Health Insurance on Safety Net Program Participation: Evidence from the ACA Medicaid Expansion

Lucie Schmidt, Lara Shore-Sheppard, and Tara Watson

NBER Working Paper No. 26504

November 2019, Revised December 2021

JEL No. I13,I38

\section{$\underline{\text { ABSTRACT }}$}

The increase in public insurance eligibility caused by the Affordable Care Act (ACA) Medicaid expansions may have had spillover effects to other public assistance programs. We explore the impact of the ACA on the Earned Income Tax Credit (EITC), the Supplemental Nutrition Assistance Program (SNAP), and Temporary Assistance to Needy Families (TANF). Our research design uses variation in Medicaid eligibility that occurs on either side of state borders: we examine county-level administrative measures of EITC and SNAP participation in contiguous county pairs that cross state lines and individual data on program participation from the American Community Survey (ACS) in contiguous sub-state geographic units. This approach allows us to focus narrowly on differences arising from the ACA Medicaid expansion choice, implicitly controlling for local economic trends that could affect safety net participation. Our results suggest that the Medicaid expansion increased participation in SNAP and TANF, and possibly in the EITC. The ACS analysis suggests that safety net impacts are mainly due to participation conditional on eligibility rather than from eligibility changes stemming from labor supply responses. It appears that ACA Medicaid eligibility reduced the marginal cost of applying in SNAP, particularly facilitating enrollment in places with low 2013 SNAP take-up rates. Our results demonstrate the potential for spillovers across safety net programs.

Lucie Schmidt

Department of Economics

Smith College

Northampton, MA 01063

and NBER

lschmidt@smith.edu

Lara Shore-Sheppard

Department of Economics

Williams College

24 Hopkins Hall Drive

Williamstown, MA 01267

and NBER

lshore@williams.edu
Tara Watson

Department of Economics

Williams College

24 Hopkins Hall Drive

Williamstown, MA 01267

and NBER

tara.watson@williams.edu 


\section{Introduction}

The safety net is a nexus of public programs addressing a partially overlapping set of needs and serving a partially overlapping set of beneficiaries. The Affordable Care Act (ACA) expanded the availability of one such program, Medicaid, to individuals who were previously categorically ineligible and to individuals such as parents who had been categorically eligible, but at lower means-tested income limits. Given connections across programs in eligibility criteria, information flows, and implementation, the expansion of public insurance eligibility may have had spillover effects to other forms of public assistance. In this paper, we explore the impact of expanded Medicaid access through the ACA on participation in the two most widely used and broadly available non-health safety net programs: the Earned Income Tax Credit (EITC) and the Supplemental Nutrition Assistance Program (SNAP), as well as on participation in the considerably smaller and more restrictive Temporary Assistance to Needy Families (TANF). Understanding how participation in non-health programs increases or decreases as the result of public health insurance expansions furthers our understanding of safety net program take-up in the United States, contributes to the policy evaluation of the ACA, and can inform future state and federal expansion decisions.

EITC and SNAP are two of the most important components of the U.S. safety net. The EITC, a refundable tax credit targeting low-income workers, is the largest cash assistance program for the non-elderly in the United States, with 26.7 million recipients in 2013 (Nichols and Rothstein 2016). SNAP (formerly known as Food Stamps) provides food assistance to more than one out of seven Americans (Hoynes and Schanzenbach 2016). In addition to having large numbers of recipients, spending on both programs is substantial, with federal expenditures of \$63 billion for the EITC in 2013 (Nichols and Rothstein 2016) and SNAP expenditures of \$74.2 
billion in 2014 (Hoynes and Schanzenbach 2016). Both EITC and SNAP are also notable because unlike many U.S. safety net programs, they have no categorical requirements such as age, presence of children, or disability status, although their eligibility standards do depend somewhat on such criteria. Nevertheless, they are in principle available to anyone, and thus when Medicaid expanded under the ACA to low-income workers without disabilities, including those without children, individuals newly eligible for Medicaid may well have qualified for these programs. By contrast, TANF, while an important component of the safety net in its prior form of Aid to Families with Dependent Children, now provides cash assistance to relatively few very low-income, typically single-parent families, with fewer than 4 million adults and children receiving cash assistance in 2014 (Ziliak 2016, Congressional Research Service 2021).

Expansion of Medicaid eligibility has several potential impacts on participation in the EITC and SNAP. First, changes in earnings due to the new Medicaid limits could affect eligibility. Individuals may be induced to reduce their income below the Medicaid income limit to qualify for Medicaid. Alternatively, the newly increased income limit relative to previous limits for some groups could allow individuals to increase earnings while still qualifying for Medicaid. Either reductions or increases in earnings could imply changes in EITC and SNAP program eligibility. However, previous literature has found little evidence of employment or earnings effects of the ACA.

In addition, expanding Medicaid access may draw individuals' attention to the existence of other public programs. This is the most likely channel through which effects on TANF participation might arise, as the TANF income limits set by states are typically much more stringent than the Medicaid income limit under the ACA. Information could also lead to increases in participation among those eligible for SNAP and the EITC. 
Finally, expanding Medicaid may reduce the marginal cost of enrolling in additional programs. Many safety net programs entail significant administrative burden—difficulty in learning about or accessing resources that is created by program design features (Herd and Moynihan 2018). Individuals incur these informational and administrative costs while enrolling in Medicaid and may find it comparatively straightforward to add one or more safety net programs to their benefits package. These cross-program spillovers may be more likely when states make it easy to qualify for and enroll in such programs, or when there are many individuals who are otherwise disconnected from the safety net.

The interconnected nature of safety net program eligibility and receipt makes examining the impacts on other programs an important aspect of evaluating the effect of changes in any one program. However, there has been relatively little work on the impact of recent Medicaid expansions on cash and food program participation. Baicker et al. (2014) analyze the Oregon Health Insurance Experiment, in which permission to apply for Medicaid was randomly assigned among a set of low-income adults. They find no effects of Medicaid expansion on TANF receipt, but they find small positive effects on the probability of SNAP receipt. Burney, Boehm, and Lopez (2021) use data on SNAP participation from the Consumer Expenditure Survey and a state difference-in-differences specification and report positive impacts of the ACA Medicaid expansion on SNAP participation. To our knowledge, no prior work examines how the ACA Medicaid expansions affected EITC receipt. ${ }^{1}$

\footnotetext{
${ }^{1}$ In related work, Chatterji, Liu, and Yörük (2019) examine the effect of the ACA's dependent care provision on family structure and program participation. They find that coverage for young adults under the age of 26 reduces single parenthood and reduces participation in SNAP, TANF, and the Special Supplemental Nutrition Program for Women, Infants, and Children (WIC). Han (2020) examines the impact of expansions in SNAP eligibility between 1997 and 2013 on a sample of households with children with income between one and two times the poverty level and finds evidence of increases in participation in other food programs, though not in Medicaid.
} 
In this paper, we exploit the fact that the Supreme Court decision of June 2012 made the Medicaid expansion optional for the states. We identify the effect of the Medicaid expansion by comparing changes in participation in contiguous pairs of sub-state geographic units (counties or Public Use Microdata Areas_PUMAs) that cross state lines where the unit on one side of the border experienced the Medicaid expansion and the unit on the other side did not. This approach allows us to focus narrowly on differences arising from the ACA Medicaid expansion choice, abstracting from potential heterogeneity in trends across broader geographic areas.

Using this border-pair method, we begin by presenting evidence of increases in insurance coverage due to the ACA Medicaid expansion that are of magnitudes similar to those found by other authors using state difference-in-differences and state synthetic control methods (Kaestner et al. 2017, Courtemanche et al. 2017). We then turn to county-level administrative measures of EITC claiming and SNAP participation. Our estimates of the effect on EITC claiming are fairly imprecise, but are suggestive of small increases in the number of tax returns claiming the EITC. For SNAP, we find that the Medicaid expansion led to a statistically significant increase in participation.

We next use individual-level data from the American Community Survey (ACS) to directly examine joint participation in Medicaid and SNAP and participation in TANF, as well as to explore heterogeneous effects and possible mechanisms. The ACS analysis confirms significant effects of the Medicaid expansion on health insurance coverage and SNAP participation, overall, across demographic groups, and within the low-income population. Our results suggest that more than a quarter of those induced to obtain public insurance as the result of ACA expansions are also induced to participate in SNAP. We also find positive impacts on participation in TANF, a program we are unable to analyze using administrative county-level 
data. It does not appear that the program participation increases are driven by labor supply changes. We therefore conclude that the safety net participation response is mainly driven by increased information or reductions in transactions costs.

Finally, we examine how the state policy environment affects the extent of ACA expansion spillovers to SNAP participation. States and localities with more relaxed SNAP eligibility rules and states with lower SNAP take-up in 2013 see bigger increases in SNAP following the ACA Medicaid expansions. We conclude that Medicaid expansions had substantial positive spillovers to SNAP participation. Our results suggest that access to Medicaid lowered the marginal cost of enrolling in other safety net programs and facilitated SNAP participation among the low-income population, particularly in areas with low initial SNAP take-up rates.

\section{Background}

The 2010 Affordable Care Act was arguably the most important piece of health care legislation in a generation. It aimed to reduce uninsurance by mandating that individuals obtain health insurance, by improving the functioning and regulation of the private market, and by significantly expanding access to public health insurance through Medicaid. In particular, it sought to expand eligibility for Medicaid to all those under 138 percent of the poverty line, representing a major change in most states. The change was especially pronounced for adults without dependents or disabilities who had been largely excluded from the program. In 2012, the Supreme Court ruled that states could not be compelled to participate in the Medicaid expansion, leading to substantial variation in the extent and timing of Medicaid expansions across states. Many states expanded in January 2014, but some expanded earlier or later, and 12 states have not (as of December 2021) changed their Medicaid eligibility limits. 
As noted above, many individuals affected by the Medicaid expansion are potentially eligible for other safety net programs. As a refundable tax credit to low-income workers, eligibility for the EITC depends on the income a family earns. The amount of the credit rises as a family's income rises (the "phase-in”) until the maximum credit has been attained, at which point the amount of the credit stays constant as income rises (the "plateau"). Above a cutoff amount of income, the amount of the credit falls as income increases (the "phase-out") until the credit falls to zero. The maximum amount of the credit depends on the number of children in the family (zero, one, two, or three or more), and the earned income limit varies depending on filing status (single/head of household or married filing jointly). In 2014, for example, the maximum credit was $\$ 496$ for a family with no qualifying children, $\$ 3,305$ with one qualifying child, $\$ 5,460$ with two qualifying children, and $\$ 6,143$ with three or more qualifying children, and the earned income limit ranged from $\$ 14,590$ for a single individual with no children to $\$ 52,427$ for a married couple with three or more children (Internal Revenue Service 2013). Participation in the program among eligible taxpayers is relatively high, with overall take-up rates estimated to be between 75 and 79 percent (Nichols and Rothstein 2016), although take-up rates vary according to demographics, family structure, and position on the EITC schedule (Jones 2014), and lack of full take-up of the EITC remains a concern among policymakers (see National Conference of State Legislatures 2018; Internal Revenue Service 2019). Many states also supplement the EITC, generally by providing additional support for those in the Federal EITC eligibility range.

Unlike the EITC, the structure of SNAP is that of a traditional means-tested transfer program: food benefits (awarded in the form of Electronic Benefit Transfer cards that can be used to purchase food from grocery stores) are highest among families with no earnings and are 
reduced at a 30 percent rate as earnings rise. To be eligible, a household must have gross monthly income below 130 percent of the poverty level and "countable" assets below \$2,250 (Hoynes and Schanzenbach 2016); these rules are somewhat relaxed in states that have adopted "broad-based categorical eligibility" criteria. SNAP is one of the few safety net programs that is available to any low-income household and is not limited to certain groups, although nonworking adults up to age 49 without children or disabilities are limited to three months of benefits within a three-year period (Hoynes and Schanzenbach 2016). Similar to the EITC, overall take-up rates are relatively high for a safety net program—75 percent in 2010—but they vary across states and groups of individuals within states (Cunnyngham 2012).

TANF provides means-tested cash benefits to low-income families with dependent children. Traditionally TANF and its predecessor Aid to Families with Dependent Children primarily served single parent families, although two-parent families and child-only cases now make up a larger share of the caseload. States set income eligibility limits for TANF, and limits are generally much lower than those for SNAP or for Medicaid under the ACA expansion. For example, in 2012 the maximum earnings eligibility for single TANF applicants with two children was below $100 \%$ of the federal poverty level in all states except Wisconsin. The median state income eligibility limit was at $48 \%$ of the federal poverty level (Falk 2014).

Many of the possible interactions between expanded Medicaid eligibility and participation in other programs arise from interactions between eligibility and labor market decisions of workers. These decisions may be either on the extensive margin (enter or leave the labor market) or on the intensive margin (work more or fewer hours conditional on working at all). The likely impacts also differ by whether the individual is single or married and by the presence or absence of children. Single and married parents had a route onto Medicaid prior to 
the ACA, but in most states needed to have very low incomes to qualify. Some parents may have chosen to stay out of the labor force to obtain health insurance; single parents were probably more likely to be on this margin. With higher Medicaid income eligibility threshold postexpansion, parents could enter the labor force without losing Medicaid coverage. In contrast, prior to the ACA non-elderly single or married adults without children or disabilities were typically ineligible for Medicaid at any income. We therefore would not expect the ACA to induce labor force entry for this group. However, childless individuals who would be earning above 138 percent of FPL in the absence of expanded Medicaid have an incentive to work less to qualify for Medicaid in expansion states. Thus, any spillovers from Medicaid expansion to the other safety net programs due to changes in labor supply will depend on the relationship between the Medicaid income eligibility limit and the limits for each program.

The relationship between the structure of the EITC and the Medicaid income eligibility limit is shown graphically in Figure 1a for single adults with and without children and in Figure $1 \mathrm{~b}$ for married couple families. The solid vertical lines indicate the typical ACA Medicaid expansion income cutoff of 138 percent of the federal poverty level (FPL) relative to the EITC schedule for each group. As shown for single parents (the top three schedules in Figure 1a) and married parents (the top three schedules in Figure 1b), labor supply entry that resulted in earnings low enough for Medicaid eligibility in expansion states likely would put parents squarely in the range of EITC receipt.

There is also an incentive for parents earning just above the Medicaid eligibility cutoff of 138 percent of the federal poverty line to reduce their earnings. However, the position of 138 percent of FPL on the EITC schedule for individuals with children indicates that those near the Medicaid cut-off would be eligible for EITC benefits with or without a small change in labor 
supply. Thus, any modest reduction in labor supply incentivized by new Medicaid eligibility would not lead to a change in EITC eligibility for parents. In sum, any labor-supply-related EITC response from parents would likely stem from labor force entry increasing EITC eligibility and participation.

The predicted effect of the ACA on EITC participation for individuals without children is different. Because EITC benefits for single or married individuals with no children phase out to zero below the Medicaid eligibility cutoff (see Figures 1a and 1b), childless individuals who reduce labor supply to qualify for expanded Medicaid could enter the EITC eligibility range. Individuals without children who would otherwise exceed the Medicaid eligibility limit and choose to exit the labor force altogether would experience no change in EITC eligibility-they would not be eligible in either case. Thus, the most likely labor-supply-related response for nonparents, if any, would be an increase in EITC stemming from a reduction in labor supply on the intensive margin.

Turning to SNAP, individuals previously ineligible for Medicaid have an incentive to work less in order to reduce their income below the new Medicaid income limit, which would lead to an increase in SNAP eligibility and participation. Alternatively, individuals who had been eligible for Medicaid previously (although at a lower income limit) have an incentive to work more, since the higher income limit could allow more earnings while still allowing the individual to qualify for Medicaid. This incentive could reduce SNAP participation if individuals work enough to lose eligibility for SNAP (though this is unlikely given the similar income thresholds for SNAP and Medicaid) or reduce the amount of SNAP benefits such that it is no longer worth the administrative hassle to participate. For TANF, because in most states the income limits are so much lower than the new Medicaid income limit, it is less likely that reductions in earnings to 
qualify for Medicaid would lead to increases in TANF eligibility. Labor market entry at low levels of income could increase SNAP or TANF eligibility due to work requirements in those programs.

In addition to labor market-related effects, there may be information/transaction costs reasons for a change in participation in any of these programs. Workers with low incomes who would not normally file a tax return may learn about EITC benefits or be nudged to file taxes when enrolling in Medicaid. In Figures 1a and 1b, dashed vertical lines indicate the tax-filing threshold for the various groups. The threshold at which an individual or family is required to file taxes is in all cases below the expanded Medicaid eligibility cutoff. It is also possible that changes in labor supply induced by the ACA put a low-income worker in a position on the EITC schedule where it is worth the effort to file a return, even if that worker would have been eligible for a small EITC benefit previously.

Gaining access to Medicaid may increase individuals’ awareness of the possibility of eligibility for SNAP or TANF, or make the application process easier. Often, government offices or non-governmental organizations that assist with Medicaid enrollment offer information about or assistance with applications for SNAP, for example. Finkelstein and Notowidigdo (2018) show that information and assistance can increase SNAP enrollment. These effects are likely to be larger in places where SNAP take-up rates are lower, and therefore there is greater unmet need.

In sum, if expanded Medicaid access changes labor supply by promoting labor market entry at a level below the new Medicaid cutoff or by reducing labor force attachment on the intensive margin to qualify, the most likely result would be to increase eligibility for the EITC, SNAP, and TANF. The information/transaction costs channel would also promote take-up of 
other programs conditional on eligibility, particularly in areas with more unmet need among lowincome individuals. The magnitude of any effect of Medicaid eligibility expansion on safety net participation is ultimately an empirical question.

\section{Empirical Approach}

As in most studies of the ACA Medicaid expansion, we use variation in Medicaid eligibility resulting from the June 2012 Supreme Court decision making the Medicaid expansion optional to the states. Unlike most other studies, however, we analyze data at the sub-state level and compare changes in program participation within contiguous pairs of counties or PUMAs that cross state lines, where one is in a state that expanded while the other is in a state that did not. ${ }^{2}$ This is the same empirical approach laid out in our previous work examining the impact of the ACA Medicaid expansion on disability program applications (Schmidt, Shore-Sheppard, and Watson 2020). Relative to a state difference-in-differences approach, the border area design has the advantage that counties or PUMAs that border each other are more likely to share similar labor markets, are more likely to be affected by the same local trends, and are more likely to share macroeconomic shocks than are those that do not share a common border (Allegretto et al. 2013; Dube, Lester, and Reich 2016). ${ }^{3}$

The border-pair approach allows us to focus narrowly on differences arising from the ACA Medicaid expansion choice by comparing changes over time in outcomes on either side of

\footnotetext{
2 This approach was pioneered in studies of the employment effects of state minimum wages (see Dube, Lester, and Reich 2010, 2016).

${ }^{3}$ One possible concern with this identification strategy is that individuals might migrate across county lines in order to obtain Medicaid. However, evidence to date suggests that any such migration is likely to be minimal. Goodman (2017) finds no evidence of a migration response to the ACA Medicaid expansion at the public-use microdata area (PUMA) level, consistent with findings by Schwartz and Sommers (2014) for earlier health insurance expansions.
} 
a state border. In this approach, the identifying assumption is that the change in the outcome of interest in the county or PUMA in the non-expanding state is a reasonable counterfactual estimate for how the outcome of interest would have changed in its neighboring county or PUMA across the border if the Medicaid expansion had not occurred.

Figure 2 illustrates the variation we use in our empirical approach: the sub-state divisions shown are counties, and contiguous border county pairs that differed in their Medicaid expansion status as of April 2014 are highlighted. In 2014, there were 488 contiguous county pairs in which one county was in a state that had adopted the Medicaid expansion and the other in a state that had not, out of a total of 1195 contiguous county pairs. There are also two sources of variation used in our analysis that are not shown in Figure 2. First, a few states had already expanded eligibility for Medicaid to some adults without disabilities prior to the ACA expansion, so the ACA expansion increased eligibility for Medicaid more in some states than in others. ${ }^{4}$ Second, states varied in when, as well as in whether, they expanded Medicaid. The modal expansion date (21 states) was January 1, 2014, but some states began to expand starting in 2010 and other states did not expand until later in 2014 or in later years. ${ }^{5}$ Our analysis considers expansions through $2016 .{ }^{6}$

\footnotetext{
${ }^{4}$ California rolled out its early Medicaid expansion on a county-by-county basis. We include this variation, which results in additional discordant pairs on the California state border prior to 2014; beginning in 2014, all states bordering California also expand, so these pairs are no longer discordant at that point.

${ }^{5}$ Recent literature points out potential biases generated by difference-in-differences models with staggered treatment timing (Goodman-Bacon 2021). We show that our results are robust to these issues below.

${ }^{6}$ Of 1195 contiguous border county pairs, 746 have discordant values for the non-categorical income limit at some point between 2010 and 2016. The number of discordant pairs by this definition ranges from 109 in 2010 to 562 in 2014.
} 
More formally, consider the following specification estimated on a sample of all counties in the continental U.S. for the period 2010-2016: ${ }^{7}$

$$
y_{c t}=\alpha+\delta \text { NoncategoricalLimit }_{s(c) t}+X_{c t} \Gamma+\varphi_{c}+\tau_{t}+\varepsilon_{c t}
$$

where $y_{c t}$ denotes the various outcomes of interest (described in detail in the Data section below) for county $c$ in time $t$, where $t$ denotes year. NoncategoricalLimit ${ }_{s(c) t}$ denotes the Medicaid noncategorical income limit, that is, the baseline income limit that applies to adults without children or disabilities (measured as a percentage of the poverty line) in effect in county $c$ in state $s$ for the majority of year $t$. Using the actual Medicaid income limit has the advantage that we incorporate information on the generosity of Medicaid eligibility prior to Medicaid expansion, thereby exploiting the fact that policy changes in some states were larger than others. The vector $X_{c t}$ includes time-varying controls such as demographic characteristics, and $\varphi_{c}$ and $\tau_{\mathrm{t}}$ are county and time fixed effects, included to account for unmeasured heterogeneity in outcomes across space and time that may be correlated with expansion status. This equation corresponds to the difference-in-differences approach used in the ACA Medicaid expansion literature thus far, although it has typically been estimated at the state level or individual level with state and year fixed effects rather than at the county level.

The identifying assumption implicit in this approach is that after removing countyspecific and time-specific fixed effects, outcomes in expansion and non-expansion counties would be changing in the same way over time if the expansion had not occurred. We estimate this model using our county-level data, clustering our standard errors at the state level to account for the fact that the variation in expansion status is at the state level. Depending on the outcome,

\footnotetext{
${ }^{7}$ For simplicity, we refer just to counties in the following discussion, but it applies to our PUMA-level analyses as well.
} 
we weight by county working age population or total population to account for the substantial variation in population size across counties.

One empirical challenge in the ACA Medicaid expansion literature is that there is a strong geographic correlation in which states chose to expand, and our outcomes of interest may be trending differently in different parts of the country. To deal with this, we use the discordant state border county approach described above. We limit the sample to contiguous border counties and restructure the data so that each county-county pair-year is one observation. Then we estimate a modified version of equation (1):

(2) $y_{c t}=\alpha+\delta$ NoncategoricalLimit $_{s(c) t}+X_{c t} \Gamma+\varphi_{c}+\tau_{p t}+\varepsilon_{c p t}$. where the subscript $p$ denotes a county-pair and $\tau_{p t}$ is a pair-specific time effect (instead of a national time effect). The use of the pair-specific time effect means that we are using only variation in expansion status within each contiguous border county pair and controlling for local economic shocks that impact both members of the county pair in a given year. The identifying assumption is thus that a difference in expansion status within a contiguous border county pair is not correlated with time-varying unobservables that affect one member of the cross-border pair but not the other. In other words, we implicitly assume that within a pair the outcome in the county with the expansion would have changed in the same way as in the non-expansion county if the expansion had not occurred. Because of the data restructuring, some county-years are observed more than once because they border multiple counties. We re-weight, ensuring that the weights across county-county-pair-year observations within a county-year sum to the county population. We cluster standard errors by state and adjust to account for duplicated observations. Because model (2) is only relevant to counties on state borders, the models in equations (1) and (2) are estimated on different samples. As a check, we estimate the difference-in- 
differences model of equation (1) on the restructured subsample of counties used in the estimation of equation (2). This check is useful in determining the effect of a different sample as well as the impact of the loss of statistical power resulting from moving to a smaller number of counties.

\section{Data}

We obtain the data for our analysis from a number of different sources, with two of our primary outcomes of interest coming from administrative data. Recipients claim the EITC via income tax filing, and the Internal Revenue Service reports the number of returns filed in each county in each year with the Earned Income Credit as part of the Statistics of Income administrative records of individual income tax returns (Forms 1040). We use data for the 20102016 tax years (filed in 2011-2017). We adjust for county size by denominating the count of returns by estimates of the working age (18-64) population from the Census Bureau, and multiply by 100 to get the number of EITC returns per 100 working age adults.

For SNAP, we use data on the number of recipients by county from the US Department of Agriculture Food and Nutrition Service National Data Bank. These data are reported biannually, in January and July, and we use the January counts for 2011-2017 to describe participation at the end of the prior year. Some states only report SNAP participation at the state level, so we are unable to use county-level data for the states of Connecticut, Idaho, Maine, Massachusetts, Missouri, Montana, Nebraska, New Hampshire, New York, Oregon, Rhode Island, Utah, Vermont, Washington, West Virginia, and Wyoming. We adjust for county size by denominating the count of SNAP participants with total population estimates in each county 
from the US Census Bureau, and multiply by 100 to get a SNAP participation rate per 100 residents.

Health insurance coverage data at the county level are available from the Census Bureau's Small Area Health Insurance Estimates (SAHIE) program, which produces estimates of the fraction with and without health insurance coverage by income group at the county level. The SAHIE estimates are model-based, incorporating information from the American Community Survey, federal tax return data, data on Supplemental Nutrition Assistance Program caseloads, Medicaid and Children's Health Insurance Program caseloads, Census population estimates, County Business Patterns, and the 2010 Census.

We determine the non-categorical Medicaid income eligibility levels applying to all adults following Medicaid expansion from a variety of sources. Prior to the ACA, parents could receive Medicaid if their incomes were below the parental eligibility limit, and a very few states had limited eligibility for non-parents. After the ACA-related Medicaid expansions, income limits were raised for adults regardless of parental or disability status in a number of states. In our empirical work, we focus on the maximum non-categorical income limit-the limit facing able-bodied non-parents. Our primary sources for Medicaid income eligibility levels are reports published by the Kaiser Family Foundation (Cohen Ross et al. 2009, Heberlein et al. 2011, Heberlein et al. 2012, Heberlein et al. 2013, Brooks et al. 2015, Brooks et al. 2016, Kaiser Commission on Medicaid and the Uninsured 2013) and the Urban Institute’s TRIM3 program rules database supplemented by information from state plan amendments available from the Centers for Medicare and Medicaid Services and state websites.

Our county level control variables include the shares of the county population that are non-Hispanic Black and Hispanic from the Census Bureau. In robustness checks, we also control 
for the unemployment rate, which we obtain from the Bureau of Labor Statistics Local Area Unemployment series. We determine which counties are contiguous using two files from the Census Bureau, a 2015 county adjacency file, which lists all adjacent counties, regardless of type of adjacency, and a county adjacency file from 1991 which gives the type of adjacency. We adjust the 2015 county-pair list to keep only counties that share a common land border or that are separated by a body of water but connected by a bridge or boat. ${ }^{8}$

Table $1 \mathrm{~A}$ presents summary statistics for the overall county administrative samples for EITC (top panel) and SNAP (bottom panel). The EITC data (which includes all states) indicate that on average there are just over 14 returns claiming the EITC per 100 working age adults, although counties range from 0 returns to over 51 per 100 adults. Medicaid eligibility expansion was in effect in 37 percent of the county-years in the sample, and the mean non-categorical income limit (including zeros) was 48 percent of the poverty line. The SNAP sample, which includes only 16,965 county-year observations due to missing data, has similar summary statistics, although county-years in the SNAP sample were somewhat less likely to have a Medicaid expansion and also had somewhat higher fractions of nonwhite populations.

Table 1B shows both the all-county and contiguous-county samples for both the EITC and SNAP data, and in addition shows the first year (2010) and last year (2016) separately. EITC and SNAP participation are similar in the sample of all counties and in the contiguous counties sample. The counties in the border sample have somewhat fewer Hispanic residents although somewhat more non-Hispanic Black residents.

\footnotetext{
${ }^{8}$ We eliminate counties that meet at a corner only and counties that are separated by a body of water and have no direct bridge or boat connection.
} 
Between 2010 and 2016 the number of EITC returns increased while the SNAP participation rate fell, consistent with the improving economy. In both EITC and SNAP data, the border county sample is more likely to have expanded Medicaid, and as a result the average noncategorical income limit is higher in the border county sample. Overall, the samples are fairly similar in their summary statistics, but because there are differences, for all of our regression analyses we estimate the model on the all-county sample and the contiguous county sample without incorporating the within-pair controls to indicate when there are differences that may arise from sample composition rather than specification.

Though county-level administrative data has the advantage of completeness and accuracy, it does not allow us to investigate the mechanisms underlying increased safety net participation nor to examine participation in multiple programs or heterogeneity in impacts. Thus, we conduct additional analyses using individual-level data from the public-use American Community Survey (ACS). County is not identified in the public-use ACS, so instead we use the consistent PUMA (Public Use Microdata Area) as the unit of analysis; these units contain at least 100,000 people and do not cross state lines. The ACS has questions about health insurance, SNAP participation, income, and labor supply. In addition, the ACS asks about receipt of TANF, a safety-net program without available county-level administrative data. Because the SNAP and income questions refer to the twelve months prior to the survey, we use the prior year's Medicaid income limit and focus on survey years 2011-2017. Table 1C presents summary statistics for the ACS. ${ }^{9}$

${ }^{9}$ The American Community Survey conducts interviews throughout the year and month of interview is not publicly available. Therefore, the reference period for someone interviewed in 2015, for example, could be any twelve months in the January 2014 to December 2015 range. 
While the border county discontinuity approach has strong intuitive appeal since it narrows the comparison to an arguably more similar counterfactual, it is important to demonstrate that restricting to bordering county pairs improves the comparison between expansion and non-expansion states. Various methods of examining the validity of border-pair models have been suggested in the literature (see Dube, Lester, and Reich 2010, 2016; Allegretto et al. 2013; and Neumark, Salas, and Wascher 2014). In Table 2, we show that pre-ACA (201011) mean absolute differences in values of our EITC and SNAP outcomes and covariates are smaller for contiguous pairs than they are for pairs formed by matching every other county with each county in the data. This suggests that county pairs that border each other are indeed more similar on observables—and therefore likely more similar on unobservables—-than randomly chosen county pairs. We have more confidence in the border county design than in a standard difference-in-differences design.

As a descriptive exercise to illustrate the county-pair design used in our analysis, we break the counties into two groups: those that ever expanded Medicaid and those that did not, where "ever expanded" is defined as having a Medicaid eligibility limit above zero for nonparents without disabilities at any point between 2010 and 2016. (Most expansions occurred in 2014 in line with the Affordable Care Act, but some states expanded earlier or later; a few had non-categorical Medicaid eligibility before 2010.) We then run regressions of our dependent variables of interest on the interaction of the "ever expanded" dummy with dummies for each year, controlling for the main effects of each year as well as other controls used in the regression analysis below. The resulting coefficients tell us about the mean difference between "ever expanded" counties and "never expanded" counties in each year in an outcome of interest, relative to the year 2010. For example, in Figure 3, we show the results of this exercise where the 
non-categorical Medicaid limit is the dependent variable (bars indicate 95 percent confidence intervals). The hollow triangles show the analysis using a standard county difference-indifferences specification, the solid triangles restrict to border counties, and the solid circles show our preferred specification which controls for border pair by year effects. As expected, regardless of specification, the difference in income limits between expansion and non-expansion counties grows dramatically in 2014 when most counties implemented their Medicaid expansion.

Figure 4 repeats this descriptive exercise using the percent uninsured as a dependent variable. In all three specifications, we see a substantial relative decline in uninsurance starting in 2014 in "ever expanded" counties. Figure 4 shows no evidence of differential trends between "ever expanded" and "never expanded" counties in uninsurance prior to expansion. Figure 4 also illustrates that the border pair specification does a particularly good job of isolating the effects of policy changes.

Figure 5 graphs the coefficients from similar regressions using EITC returns per 100 working-age adults as the dependent variable. The standard county differences specification (hollow triangles) shows somewhat higher numbers of EITC returns in "ever expanded" counties in the pre-period. Once we control for border-pair by year dummies (solid circles), this pre-ACA difference is largely eliminated. Focusing on the preferred border-pair specification, it appears that EITC returns increase around 2014 in expansion counties relative to bordering counties.

Finally, we show the same graphical illustration for SNAP participation in Figure 6. Using the preferred border-pair specification, SNAP participation appears to increase in a relative sense around 2014 in expansion counties relative to their bordering counties, but then the two groups converge. These estimates are noisy, however, in part because many states are excluded from the analysis. Figure 7 shows a similar pattern of results examining SNAP 
participation in the ACS, comparing results from an all-PUMA difference-in-differences specification to a border-PUMA specification, and shows elevated SNAP receipt that persists throughout our time period.

These figures are meant to provide a descriptive representation of our empirical approach. They do not account for when a particular state experienced its expansion, nor do they account for differing levels of the non-categorical income limit in effect in different states at different times. We next present our results from our full analyses that take these differences into account.

\section{Results from County-Level Data}

\section{A. Uninsurance}

Table 3 shows the effects of the ACA Medicaid expansions on uninsurance, controlling for the race/ethnicity composition of the population. Column 1 shows the analysis for the all counties sample with county fixed effects and year fixed effects, using the standard differencein-differences model with a continuous treatment variable shown in equation (1), while column 2 uses the same specification but restricts to the subsample of contiguous county pairs. The difference between columns 1 and 2 thus reflects differences in the border counties sample relative to the all counties sample. The results in column 1 suggest that moving from a noncategorical income limit of 0 percent to 100 percent of the federal poverty level reduces uninsurance by 0.6 percentage points, while in column 2 , the point estimate is larger in magnitude at -1.3. Column 3 incorporates county-pair by year fixed effects as described in equation (2) above. The county-pair approach suggests a reduction of uninsurance of about 1.6 percentage points for an increase in the income limit from 0 percent to 100 percent. For context, 
the typical expansion moved from an income limit of 0 percent to 138 percent of the poverty line, and the mean uninsurance rate in 2010 (prior to the ACA) was 18.7 percent. Therefore, a typical expanding county reduced uninsurance by about 2.2 percentage points relative to an adjacent non-expanding county, around 12 percent of the baseline uninsurance level.

Columns 4 through 6 of Table 3 repeat the exercise examining the percent of the population with family incomes under 250 percent of the federal poverty level that is uninsured as the outcome. The effects of the Medicaid expansion are concentrated in this lower-income group, so it is not surprising that the coefficients are larger in magnitude. The preferred specification in column 6, which includes county-pair by year fixed effects, shows that increasing the Medicaid income limit from 0 to 100 percent of the poverty line reduced uninsurance 2.8 percentage points. The estimate implies that expansion counties moving from 0 to 138 percent of the poverty line would have 3.8 percentage points lower uninsurance in the low-income group than bordering counties, again a 12 percent reduction relative to the baseline of 29.5 percent uninsurance in 2010. The findings corroborate the findings of prior research using state difference-in-differences or incorporating within-state variation in prior uninsured rates that shows the ACA Medicaid expansions reduced uninsurance (for example, Kaestner et al. 2017 and Courtemanche et al. 2017).

\section{B. Earned Income Tax Credit}

Our results for estimation of equations (1) and (2) for tax returns with an EITC per 100 working age adults are shown in Table 4. The point estimates are positive and significant in the standard difference-in-differences specifications in column 1 (all counties) and column 2 (contiguous counties), with estimated coefficients that suggest an increase of 0.17 percentage points. Our preferred estimate in column 3 using the county-pair identification strategy is 
roughly half the magnitude and is no longer statistically different from zero. The point estimate implies an effect size of 0.09 percentage points, suggesting that an increase in the Medicaid income limit from 0 to 138 percent is associated with an increase of 0.12 EITC returns per 100 working-age adults. Since the mean in 2010 was roughly 14 EITC returns per 100 working-age adults, this point estimate implies that the increase was quite small, approximately 1 percent of the baseline level. For comparison, Kopczuk and Pop-Eleches (2007) estimate that state electronic filing programs increased EITC returns by around 10 percent among the target income group. Overall, our results suggest that the expansion of Medicaid eligibility under the ACA may have led to a small increase in EITC filing, but the preferred specification does not show a statistically significant relationship. The point estimate is about half of the size of that suggested by the standard difference-in-differences approach, which may be biased upward by the preexisting differential trends in EITC returns between expansion and nonexpansion counties that were evident in Figure 5.

\section{Supplemental Nutrition Assistance Program}

Next, we turn to our results for the SNAP administrative data (Table 5). As noted earlier, these results rely on a smaller sample because a number of states do not report county-level SNAP data. We find statistically significant and positive estimates for the effect of the Medicaid non-categorical income limit on SNAP participation per 100 population. The coefficient of 0.43 on our preferred specification (column 3) indicates that an increase in the Medicaid noncategorical income limit from 0 to 138 percent of the poverty level led to a statistically significant change of 0.6 additional SNAP participants per 100 people, a 4 percent increase relative to the mean rate of 15 percent SNAP participation. The estimates are about one-quarter of the effect size on uninsurance. 


\section{State-Level Analyses}

To examine the role of data and identification strategy in our results, we show estimates using state-level data and using two-way fixed effects, as is more common in the literature. Panel A of Table 6 shows this analysis for the EITC. The first two columns repeat the results from Table 4 using the standard county difference-in-differences and county-border pair designs. Columns (3) and (4) show results from similar analyses done at the state level, with column (4) incorporating state border pair controls. The state difference-in-differences estimate in column (3) is statistically significant, and as expected it is similar to the estimate from the county data using state difference-in-differences variation. When either county or state border pairs are introduced, there is no longer a statistically significant relationship between ACA Medicaid expansions and EITC filing.

Panel B of Table 6 contains the results for SNAP. Additional states are available because some states provide state-level but not county-level information, so results are shown for two different groups of states - all states reporting state-level data and only states that also report SNAP information at the county level. The coefficients are fairly similar in magnitude in all specifications and marginally significant in three of the four state-level models.

In sum, the key SNAP results-that Medicaid expansions are associated with an increase in SNAP participants-are in evidence regardless of whether a county border-pair, a state borderpair, or a state difference-in-differences approach is used. For the EITC, the state border pair approach yields coefficients that are fairly similar to the border county pair approach, and these estimates are substantially smaller in magnitude than the standard difference-in-differences at both the state and the county level. Consistency across specifications is sensitive to the particular 
outcome of interest, and we believe the border county pair approach generally offers a more reliable estimate of the effect of Medicaid expansions.

\section{E. Robustness}

Appendix Tables 1 and 2 present results from several robustness checks using our borderpair by year specification. For the EITC (Appendix Table 1), we add controls for the percent of the population that is 65 and older (column 2) and the (potentially endogenous) unemployment rate (column 3). Our main coefficient of interest is reduced slightly with the addition of these controls, not changing our finding of no statistically significant relationship between the Medicaid expansion and EITC participation. In columns 4 through 6, we present the same regressions, but with a binary “expansion” variable instead of our continuous non-categorical Medicaid limit. We consider a county to have expanded in a given year if it has a non-categorical Medicaid limit greater than zero. Our conclusion from this alternate specification is the same.

Robustness checks for SNAP are in Appendix Table 2. The models are similar to the EITC regressions in Appendix Table 1, except that columns 2, 3, 5, and 6 also control for the presence in the county of an ABAWD (able-bodied adult without dependents) waiver which relaxed additional work requirements for SNAP among non-parents under age 50, who are restricted to three months of benefits over a three year period if they do not work. ${ }^{10}$ The results consistently point to a positive relationship between Medicaid expansion and SNAP participation, and the magnitudes of the estimated effects are generally similar across specifications as well.

${ }^{10}$ The ABAWD variables are generated by triangulating data from the U.S. Department of Agriculture, the Center for Budget and Policy Priorities, state websites, and data generously shared by Brian Stacy at the World Bank. 
Finally, a recent literature suggests that difference-in-differences analysis with staggered timing, implemented through two-way fixed effects (TWFE) models, can lead to biased results (Goodman-Bacon 2021). While Carey, Miller, and Wherry (2020) show that the staggered timing of the Medicaid expansion does not appear to create large biases for their outcomes (utilization of health care among Medicare beneficiaries), we directly test the robustness of our SNAP results to this critique. For this analysis, we use the Stata bacondecomp package (Goodman-Bacon, Goldring, and Nichols 2019) with a simple county-level TWFE analysis (similar to the one presented in Column (1) of Table 5) and a binary expansion variable to investigate the role of staggered timing. ${ }^{11}$ This decomposition shows the weight that each type of "treatment” versus "control" comparison has in the overall estimate. As shown in Figure 8, the Bacon decomposition suggests that the majority (82 percent) of our 0.575 estimate is driven by four comparisons: never-treated to 2012 expanders, never-treated to 2014 expanders, nevertreated to 2015 expanders, and 2014 expanders to 2012 expanders. The DD estimates on the first three are all positive, while the estimate on the last (and the only invalid comparison in the presence of dynamic treatment effects) is negative. If we manually take out the invalid comparisons and reweight our estimates, the effect of the ACA Medicaid expansion on SNAP participation becomes even larger in magnitude. As an additional robustness test, we have estimated regressions comparing all states that expanded in a given year with those that never expanded (i.e., compare states that expanded in 2011 with states that never expanded, compare states that expanded in 2012 with those that never expanded, etc., separately for all expansion

\footnotetext{
${ }^{11}$ Specifically, we use a two-way fixed effects model with a binary treatment variable representing expansion, defined as any non-categorical Medicaid eligibility for adults. The sample counties are restricted to be a balanced panel and to eliminate one state which mas not monotonically increasing in treatment status.
} 
years through 2016). Effects of the Medicaid expansion on SNAP participation from these regressions are positive in all years, though they vary in statistical significance.

\section{Results from the American Community Survey}

Overall, our county-level analyses show mixed evidence that EITC participation was affected by the ACA Medicaid expansion, but consistent evidence that the expansion led to an increase in SNAP participation. In this section, we use individual-level data from the ACS to further investigate the connections between safety net programs. Specifically, we look at joint program participation as well as participation in TANF which is not available in county-level data. We also examine heterogeneous impacts across groups based on age and family structure because these groups face different Medicaid, SNAP, and EITC eligibility criteria. In addition, we directly examine one potential mechanism, changes in program eligibility through changes in labor supply, and explore how state policy environments might affect spillovers across programs.

Counties are not available in the public-use ACS. Instead, we identify contiguous PUMAs and implement analyses with PUMA-pair-year fixed effects that are analogous to our county-level regressions. We examine all adults ages 25 to 64 in border PUMAs, and then we split the sample into four demographic groups based on parental status and age, characteristics that affect the program eligibility rules faced by an individual. Parents, who faced somewhat less restrictive Medicaid eligibility criteria pre-ACA, are defined as those with a biological, step, or adoptive child under 19 in the home, or unmarried partners of those with children in the home. Among parents, we split the sample between married and unmarried given the differing EITC rules for these groups. Among non-parents, we split the sample into those ages 25 to 49, and therefore potentially affected by SNAP work requirements for able-bodied adults without 
dependents, and those ages 50 to 64 . We end up with four demographic subgroups: younger nonparents, older non-parents, married parents, and single parents.

As in the county pair analysis, we examine the effect of a change in the non-categorical Medicaid income limit. We include indicator controls for demographic group (four groups based on parental status, marital status, and age, as described above), non-Hispanic Black interacted with demographic group, Hispanic interacted with demographic group, female, education high school, education some college, and education college grad. We also control for age and age squared.

Results for the individual-level analyses using PUMA-pairs are shown in Table 7. Each coefficient represents the key estimate on the non-categorical income limit from a different regression that includes PUMA-pair by year fixed effects, equivalent to column 3 of our countylevel analysis tables. Clustered standard errors are shown in parentheses. Below clustered standard errors, we include False Discovery Rate q-values to reflect inference with multiple hypothesis tests, as suggested by Andersen (2008). The asterisks on the regression coefficients refer to p-values unadjusted for multiple hypothesis testing, whereas the asterisks on the bracketed q-values refer to the q-value significance levels.

\section{A. Health Insurance and Safety Net Participation}

We first investigate whether this new dataset and empirical approach yields the same basic findings about the effect of the policy change on insurance that we document in the countylevel data. As expected, we find economically meaningful and statistically significant increases in health insurance for all demographic groups in expansion PUMAs relative to those in adjacent non-expansion PUMAs (first row of Table 7; baseline mean values are shown in Appendix Table 3). The results are not directly comparable to those in Table 3 because Table 3 reflects the full 
population rather than adults age 25 to 64, and the analyses cover different geographic areas (border counties versus border PUMAs). Nevertheless, the estimate in column 1 of a 1.97 percentage point increase in any health insurance for an increase in the income limit from 0 to 100 percent of the poverty line is fairly similar to the estimated 1.62 percentage point decline in uninsurance in Table 3.

A strength of the ACS dataset is that it allows us to explore heterogenous effects by demographic subgroups and to distinguish between public and private health insurance. Effects on insurance are most pronounced for younger non-parents and single parents (see columns (2) and (4) of Table 7). Insurance effects are larger for the sub-sample under 130 percent of the poverty line. The increases in insurance are driven by increases in public health insurance in expansion PUMAs, partially offset by reductions in private insurance. These estimates of impacts of the expansion on any insurance, public insurance, and private insurance are fairly similar in magnitude to previous estimates in the literature using different identification strategies.

Turning next to other safety net program participation, the ACS results using the border PUMA design in Table 7 show positive impacts on SNAP participation, consistent with the results from the analysis of county administrative data. The coefficient in the full sample analysis suggests a 0.87 percentage point increase in the probability a sample adult lives in a SNAP household. The magnitude is larger than the 0.43 percentage point increase identified in the border county analysis, perhaps due to the somewhat different ages and locations of the population being analyzed.

The results in Table 7 broken down by demographic group show that the effect on SNAP holds across demographic groups. It is larger under 130 percent of the poverty line (the SNAP 
income eligibility threshold) for each group and overall, indicating that changes in income eligibility alone are not driving the results. The magnitude of the effect for the sample under 130 percent of the poverty line is similar across demographic groups although with a slightly larger impact for younger non-parents, the group that also shows the largest impact on health insurance.

We also examine multiple program participation. Medicaid eligibility expansion is associated with an increase in those who participate in both Medicaid and SNAP, and a decline in those who participate in SNAP without Medicaid. The numbers imply that more than a quarter of those induced to obtain public insurance as the result of ACA expansions (2.93 of every 100 adults for an increase in the income limit of 100 percent of the poverty line) are also induced to participate in SNAP (0.87 of every 100 adults) when they otherwise would not have done so. These numbers are quite similar to what is indirectly implied by the county-level analysis, in which the decline in uninsurance is roughly four times the magnitude of the increase in SNAP. However, despite the fact that income eligibility levels are similar for Medicaid and SNAP, the Medicaid expansion led to an increase in individuals reporting receiving Medicaid but not SNAP of between 1 and 1.9 percentage points, depending on demographic group, suggesting that any increase in information or reduction in transactions costs was not sufficient to enroll all individuals eligible for both programs.

Table 7 also shows coefficients for participation in TANF. These results suggest an increase in TANF participation, particularly among single parents (the group most often eligible for TANF), in expansion PUMAs. The coefficient for single parents implies an increase in participation of 0.71 percentage points (on a base of 6 percent) from a 100 percentage-point increase in the Medicaid income limit. This finding is consistent with new Medicaid enrollees learning about or getting access to other safety net programs. Unfortunately, EITC receipt is not 
asked in the ACS, so we are only able to examine mechanisms affecting EITC eligibility due to changes in earned income. ${ }^{12}$ We discuss this in the following sub-section.

\section{B. Mechanisms}

We next investigate labor supply responses that could explain a link between Medicaid eligibility and participation in other safety net programs. As noted above, Medicaid expansions could affect labor supply decisions in either direction, which in turn may affect eligibility for other programs.

In Table 8, we start by examining EITC eligibility, which could be more prevalent if individuals enter the labor force as the result of the ACA, or if individuals reduce their labor supply so that they fall within the EITC earnings range. The point estimate in column (1) of Table 8 does suggest a small increase in imputed EITC eligibility (0.22 percentage points for a 100 percentage-point increase in the Medicaid income limit), relative to a base of 15 percent. However, the coefficient does not retain significance after adjusting for multiple hypothesis testing. The largest point estimate is for single parents. This finding, though small and statistically fragile, is consistent with a model of labor supply responses to increased Medicaid income limits among single parents generating spillover effects onto EITC eligibility. As noted below, other evidence in Table 8 points to labor force entry among single parents as the result of ACA expansions, but these findings are sensitive to multiple hypothesis adjustments.

Labor supply responses could also help explain the SNAP participation effects by affecting SNAP eligibility. We look at whether Medicaid expansions impact the probability of

\footnotetext{
${ }^{12}$ We attempted to examine the information mechanism for EITC participation in our county data using the measure of knowledge about the EITC in the county developed by Chetty, Friedman, and Saez (2013) to examine whether there were differential responses to Medicaid expansion in counties with high versus low levels of knowledge, but the results were statistically inconclusive.
} 
ACS respondents being under 130 percent of the poverty line, the eligibility threshold for SNAP. There is suggestive evidence shown in Table 8 that this is the case for one group, older nonparents, consistent with an ACA-induced reduction in labor supply for this group. However, the statistical significance does not hold up to adjustment for multiple hypothesis testing, and we do not see other significant indications of labor supply response for this group.

Prior literature based on state difference-in-differences models has found limited evidence of a labor supply response to ACA Medicaid expansions (e.g., Gooptu et al. 2016, Kaestner et al. 2017, Frisvold and Jung 2018, Leung and Mas 2018). The overall results of our ACS border PUMA analysis of labor supply measures, including on both the extensive and intensive margins, are consistent with this characterization. In Table 8, most coefficients are not statistically significant after adjusting for multiple hypothesis testing. We do note two labor supply patterns worthy of further investigation in future work. First, younger adults who are not parents appear to increase their labor supply to a small degree on the intensive margin. This is not predicted by theory, though could relate to changing labor supply decisions within the household. Second, to a small degree, single parents appear to enter the labor market in response to the ACA. This is consistent with parents gaining the ability to work at higher earnings levels without forgoing Medicaid benefits.

These small estimated labor supply effects suggest that increased information or reduced transaction costs are the primary explanations for increased levels of participation in the SNAP program resulting from the Medicaid expansion. It is possible that changes in labor supply may have contributed to small changes in EITC participation, but we lack necessary statistical precision to draw any firm conclusions. Coupled with the large SNAP changes we see in Table 7 
for those who are under the eligibility threshold, we infer that Medicaid expansions mainly induced SNAP participation through an information/transaction costs channel.

\section{Policy Environment}

We further probe the relationship between Medicaid expansion and SNAP participation by investigating whether baseline policy environments affect the magnitude of the estimated spillovers between the ACA Medicaid expansion and SNAP participation. Specifically, we investigate whether the SNAP response is bigger in states in which (a) there are relaxed SNAP eligibility requirements, (b) the SNAP enrollment process has fewer barriers, and (c) there existed a large pool of individuals who were income-eligible for SNAP but were not participating prior to 2014.

For this analysis, we move to a difference-in-differences approach to maximize statistical power. ${ }^{13}$ Column (1) of Table 9 implements a two-way fixed effects model in the American Community Survey sample. We see a statistically significant positive impact of Medicaid expansion on SNAP, somewhat smaller than but consistent with the PUMA-pair estimates in Table 7. These impacts are statistically significant for younger and older non-parents, those under 130 percent of the poverty line, and the adult population as a whole.

In columns (2) through (4) of Table 9, we examine whether the 2013 state and local policy environment affects SNAP spillovers. Though SNAP is a federal program, states have discretion over implementation details that impact participation. We start by examining the differential impacts based on an index of SNAP eligibility, which is higher in states with more

\footnotetext{
${ }^{13}$ Exploring interactive effects requires comparisons across four types of places-those with and without expansion, and within expansion and non-expansion places those with differing levels of the relevant characteristic. There are an inadequate number of discordant border pairs to make these comparisons using the border pair strategy.
} 
generous eligibility rules. We consider the 2013 presence of two policies: an ABAWD work requirement waiver in the majority of the PUMA, making it easier for adults without dependents to qualify, and broad-based categorical eligibility (BBCE) for SNAP in the state. BBCE relaxes some income and asset requirements for low-income individuals who participate in non-cash TANF programs. ${ }^{14}$ The eligibility index is equal to 2 if both policies are in place, 1 if just one of these policies is in place, and 0 if neither. Column (2) of Table 9 shows that states with more relaxed SNAP eligibility rules indeed had more SNAP take-up as a result of ACA expansions, although we cannot rule out the possibility that other state factors correlated with SNAP eligibility rules might be driving this result.

To investigate the role of administrative burden, Column (3) uses a measure of SNAP ease of enrollment generated from components of the SNAP availability index in Ganong and Liebman (2018). States can choose to implement policy options that reduce administrative burden and make it easier for potential recipients to access benefits. The enrollment index combines measures of three state policy choices regarding SNAP: whether states have call centers, whether they allow on-line applications, and whether Supplemental Security Income recipients have a simplified application process through the Combined Application Project (CAP). The enrollment index ranges from 0 to 3 , reflecting the number of the three policy options that are in place as of 2013. Column (3) of Table 9 shows no evidence that these factors are correlated with spillover effects of the ACA onto SNAP participation. This absence of a significant relationship does not necessarily imply that administrative burden is an unimportant determinant of safety net take-up, but rather that these particular measures of administrative

\footnotetext{
${ }^{14}$ Data on broad-based categorical eligibility and most other state policy options are provided by on-line data accompanying Ganong and Liebman (2018) and are based on SNAP state policy option reports.
} 
burden are not strong predictors of cross-program spillovers, perhaps because they do not adequately capture heterogeneity in the marginal cost of applying to SNAP at the time of Medicaid enrollment.

Finally, in column (4), we consider a measure of unmet need in the SNAP program. Specifically, we use estimates of state SNAP take-up rates in 2013 from Cunnyngham, Sukasih, and Castner (2016) to calculate the estimated fraction of SNAP-eligible people in the state who do not participate. The results suggest a strong positive relationship between the unmet need in a state (defined as one minus the SNAP take-up rate) and the impact of Medicaid expansion. States with more scope to enroll eligible people in SNAP did so to a greater extent as a result of Medicaid expansion. For example, the estimated coefficient indicates that Colorado, with estimated 2013 SNAP take-up of 84 percent, would be predicted to have an increased SNAP participation of 0.8 percentage points associated with full ACA expansion, whereas Nevada, with estimated 2013 SNAP take-up of 66 percent, would have a 1.9 percentage point increase in SNAP. It is likely that ACA expansions encouraged some of those who were previously disconnected from safety net programs to enroll in multiple programs at once.

\section{Conclusion}

Our results suggest that the Medicaid expansion does affect safety net participation in counties (or PUMAs) in states that expanded relative to nearby counties (or PUMAs) in states that did not expand. In both county-level administrative data and the American Community Survey, we find robust evidence that the Medicaid expansion increased SNAP take-up, with about a quarter of those gaining public insurance due to the Medicaid expansion also induced to participate in SNAP. We also find evidence of increases in TANF receipt in the ACS. However, 
while administrative data at the county and state levels show suggestive evidence of small increases in EITC receipt, these increases are not statistically significant in the preferred borderpair specifications.

Our analysis of mechanisms using the American Community Survey shows no strong evidence of changes in eligibility due to earnings or income, but instead points to information/transaction costs as the main explanation for the observed association between Medicaid and SNAP. It is likely that the process of enrolling in Medicaid facilitates SNAP enrollment. These spillovers were most pronounced in places with more flexible SNAP eligibility rules and low SNAP take-up in 2013, suggesting that the ACA expansion helped to connect disconnected individuals with unmet need to the safety net.

The finding that Medicaid expansions promote SNAP, TANF, and perhaps EITC participation suggests the federal costs associated with the ACA are greater than the direct costs of the program itself. Similarly, states considering Medicaid expansions might consider additional inflows of federal SNAP and EITC dollars as a benefit of making Medicaid income eligibility limits more generous. More broadly, the findings suggest the presence of important spillover effects across safety net programs. 


\section{References}

Allegretto, Sylvia, Arindrajit Dube, Michael Reich, and Ben Zipperer. 2013. "Credible Research Designs for Minimum Wage Studies.” IZA Discussion Paper No. 7638.

Andersen, Michael L. 2008. "Multiple Inference and Gender Differences in the Effects of Early Intervention: A Reevaluation of the Abecedarian, Perry Preschool, and Early Training Projects.” Journal of the American Statistical Association 103(484): 1481-1495.

Baicker, Katherine, Amy Finkelstein, Jae Song, and Sarah Taubman. 2014. "The Impact of Medicaid on Labor Market Activity and Program Participation: Evidence from the Oregon Health Insurance Experiment.” American Economic Review 104(5):322-328.

Burney, Shaheer, Rebecca Boehm, and Rigoberto Lopez. 2021. "The Impact of the ACA Medicaid Expansion on SNAP Participation.” Food Policy 101(May).

Brooks, Tricia, Joe Touschner, Samantha Artiga, Jessica Stephens, and Alexandra Gates. 2015. "Modern Era Medicaid: Findings from a 50-State Survey of Eligibility, Enrollment, Renewal, and Cost-Sharing Policies in Medicaid and CHIP as of January 2015.” Kaiser Commission on Medicaid and the Uninsured Policy Brief \#8681.

Brooks, Tricia, Sean Miskell, Samantha Artiga, Elizabeth Cornachione, and Alexandra Gates. 2016. "Medicaid and CHIP Eligibility, Enrollment, Renewal, and Cost-Sharing Policies as of January 2016: Findings from a 50-State Survey.” Kaiser Commission on Medicaid and the Uninsured Policy Brief \#8824.

Carey, Colleen M., Sarah Miller, and Laura R. Wherry. 2020. “The Impact of Insurance Expansion on the Already Insured: The Affordable Care Act and Medicare.” American Economic Journal: Applied Economics 12(4): 288-318.

Chatterji, Pinka, Xiangshi Liu, and Baris K. Yörük. 2019. The Effects of the 2010 Affordable Care Act Dependent Care Provision on Family Structure and Public Program Participation Among Young Adults.” Review of the Economics of the Household 17:1133-1161.

Chetty, Raj, John Friedman and Emmanuel Saez. 2013. "Using Differences in Knowledge Across Neighborhoods to Uncover the Impacts of the EITC on Earnings," American Economic Review 103(7): 2683-2721.

Cohen Ross, Donna, Marian Jarlenski, Samantha Artiga, and Caryn Marks. 2009. “A Foundation for Health Reform: Findings of a 50 State Survey of Eligibility Rules, Enrollment and Renewal Procedures, and Cost-Sharing Practices in Medicaid and CHIP for Children and Parents During 2009.” Kaiser Commission on Medicaid and the Uninsured Policy Brief \#8028.

Congressional Research Service. 2021. “The Temporary Assistance for Needy Families (TANF) Block Grant: Responses to Frequently Asked Questions.” Updated December 14, 2021. Report RL32760. https://crsreports.congress.gov/product/pdf/RL/RL32760. 
Courtemanche, Charles, James Marton, Benjamin Ukert, Aaron Yelowitz, and Daniela Zapata. 2017. "Early Impacts of the Affordable Care Act on Health Insurance Coverage in Medicaid Expansion and Non-Expansion States.” Journal of Policy Analysis and Management 36(1): 178210.

Cunnyngham, Karen E. 2012. "Reaching Those in Need: State Supplemental Nutrition Assistance Program Participation Rates in 2010.” Alexandria, VA: U.S. Department of Agriculture, Food and Nutrition Service, February. https://fnsprod.azureedge.net/sites/default/files/ops/Reaching2010.pdf

Cunnyngham, Karen, Amang Sukasih, and Laura Castner. 2016. “Empirical Bayes Shrinkage Estimates of State Supplemental Nutrition Assistance Program Participation Rates in Fiscal Year 2011 to Fiscal Year 2013 for All Eligible People and the Working Poor.” Mathematica Policy Research, Report to the U.S. Department of Agriculture. https://www.mathematica.org/publications/empirical-bayes-shrinkage-estimates-of-snapparticipation-rates-in-fiscal-year-2011-to-fiscal-year.

Dube, Arindrajit, T. William Lester, and Michael Reich. 2010. "Minimum Wage Effects Across State Borders: Estimates Using Contiguous Counties.” Review of Economics and Statistics 92(4): 945-964.

Dube, Arindrajit, T. William Lester and Michael Reich. 2016. "Minimum Wage Shocks, Employment Flows, and Labor Market Frictions.” Journal of Labor Economics 34(3): 663-704.

Falk, Gene. 2014. “Temporary Assistance for Needy Families (TANF): Eligibility and Benefit Amounts in State TANF Cash Assistance Programs.” Congressional Research Service Report, July 22.

Finkelstein, Amy and Matthew J. Notowidigdo. 2018. “Take-Up and Targeting: Experimental Evidence from SNAP.” National Bureau of Economic Research Working Paper 24652.

Frisvold, David E. and Younsoo Jung. 2018. “The impact of expanding Medicaid on health insurance coverage and labor market outcomes.” International Journal of Health Economics and Management 18 (2): 99-121.

Ganong, Peter and Jeffrey B. Liebman. 2018. "The Decline, Rebound, and Further Rise in SNAP Enrollment: Disentangling Business Cycle Fluctuations and Policy Changes.” American Economic Journal: Economic Policy 10(4): 153-176.

Goodman, Lucas. 2017. "The Effect of the Affordable Care Act Medicaid Expansion on Migration.” Journal of Policy Analysis and Management 36(1): 211-238.

Goodman-Bacon, Andrew. 2021. "Difference-in-Differences with Variation in Treatment Timing.” Journal of Econometrics 225(2): 254-277. 
Goodman-Bacon, Andrew, Thomas Goldring, and Austin Nichols. 2019. "BACONDECOMP: Stata module to perform a Bacon decomposition of difference-in-differences estimation,” Statistical Software Components S458676, Boston College Department of Economics, revised 15 Sep 2019.

Gooptu, Angshuman, Asako S. Moriya, Kosali I. Simon, and Benjamin D. Sommers. 2016. "Medicaid Expansion Did Not Result In Significant Employment Changes Or Job Reductions In 2014.” Health Affairs 35 (1): 111-118.

Han, Jeehoon. 2020. "SNAP Expansions and Participation in Government Safety Net Programs.” Economic Inquiry 58(4): 1929-1948.

Heberlein, Martha, Tricia Brooks, Jocelyn Guyer, Samantha Artiga, and Jessica Stephens. 2011. "Holding Steady, Looking Ahead: Annual Findings of a 50-State Survey of Eligibility Rules, Enrollment and Renewal Procedures, and Cost-Sharing Practices in Medicaid and CHIP, 20102011.” Kaiser Commission on Medicaid and the Uninsured Policy Brief \#8130.

Heberlein, Martha, Tricia Brooks, Jocelyn Guyer, Samantha Artiga, and Jessica Stephens. 2012. "Performing Under Pressure: Annual Findings of a 50-State Survey of Eligibility, Enrollment, Renewal, and Cost-Sharing Policies in Medicaid and CHIP, 2011-2012.” Kaiser Commission on Medicaid and the Uninsured Policy Brief \#8272.

Heberlein, Martha, Tricia Brooks, Joan Alker, Samantha Artiga and Jessica Stephens. 2013. "Getting into Gear for 2014: Findings from a 50-State Survey of Eligibility, Enrollment, Renewal, and Cost-Sharing Policies in Medicaid and CHIP, 2012-2013.” Kaiser Commission on Medicaid and the Uninsured Policy Brief \#8401.

Herd, Pamela and Donald P. Moynihan. 2018. Administrative Burden: Policymaking by Other Means, New York: Russell Sage Foundation.

Hoynes, Hilary and Diane Whitmore Schanzenbach. 2016. "US Food and Nutrition Programs.” In Economics of Means-Tested Transfer Programs in the United States, volume 1, Robert Moffitt, ed., Chicago: University of Chicago Press, pp. 219-301.

Internal Revenue Service. 2013. “Revenue Procedure 2013-35.” https://www.irs.gov/pub/irsdrop/rp-13-35.pdf. . 2019. “EITC Awareness Day.” https://www.eitc.irs.gov/partner-toolkit/eitc-awarenessday/eitc-awareness-day-2

Jones, Maggie R. 2014. “Changes in EITC Eligibility and Participation, 2005-2009.” CARRA Working Paper \#2014-04. Washington, DC: US Census Bureau, July. https://www.census.gov/content/dam/Census/library/working-papers/2014/adrm/carra-wp-201404.pdf. 
Kaestner, Robert, Bowen Garrett, Jiajia Chen, Anuj Gangopadhyaya, and Caitlyn Fleming. 2017. "Effects of ACA Medicaid expansions on health insurance coverage and labor supply." Journal of Policy Analysis and Management 36(3): 608-642.

Kaiser Commission on Medicaid and the Uninsured. 2013. "A Look at Section 1115 Medicaid Demonstration Waivers Under the ACA: A Focus on Childless Adults.” Issue Brief. https://kaiserfamilyfoundation.files.wordpress.com/2013/10/8499-a-look-at-section-1115medicaid-demonstration-waivers.pdf

Kopczuk, Wojciech and Cristian Pop-Eleches. 2007. "Electronic Filing, Tax Preparers, and Participation in the Earned Income Tax Credit.” Journal of Public Economics 91: 1351-1367.

Leung, Pauline, and Alexandre Mas. 2018. "Employment Effects of the Affordable Care Act Medicaid Expansions.” Industrial Relations: A Journal of Economy and Society 57 (2): 206-234.

National Conference of State Legislatures. 2018. “Tax Credits for Working Families: Earned Income Tax Credit (EITC).” http://www.ncsl.org/research/labor-and-employment/earnedincome-tax-credits-for-working-families.aspx

Neumark, David, J. M. Ian Salas, and William Wascher. 2014. "Revisiting the Minimum WageEmployment Debate: Throwing Out the Baby with the Bathwater?” Industrial and Labor Relations Review 67(Supplement):608-648.

Nichols, Austin and Jesse Rothstein. 2016. “The Earned Income Tax Credit.” In Economics of Means-Tested Transfer Programs in the United States, volume 1, Robert Moffitt, ed., Chicago: University of Chicago Press, pp. 137-218.

Schmidt, Lucie, Lara Shore-Sheppard, and Tara Watson. 2020. "The Impact of the ACA Medicaid Expansion on Disability Program Applications.”

American Journal of Health Economics 6(4): 444-476.

Schwartz, Aaron and Benjamin D. Sommers. 2014. "Moving for Medicaid? Recent Eligibility Expansions Did Not Induce Migration From Other States.” Health Affairs 33(1):88-94.

Ziliak, James P. 2016. “Temporary Assistance for Needy Families.” In Economics of MeansTested Transfer Programs in the United States, volume 1, Robert Moffitt, ed., Chicago: University of Chicago Press, pp. 303-393. 
Figure 1a: EITC Schedule for Single Individuals with and without Children EITC Schedule for Single Individuals With and Without Children

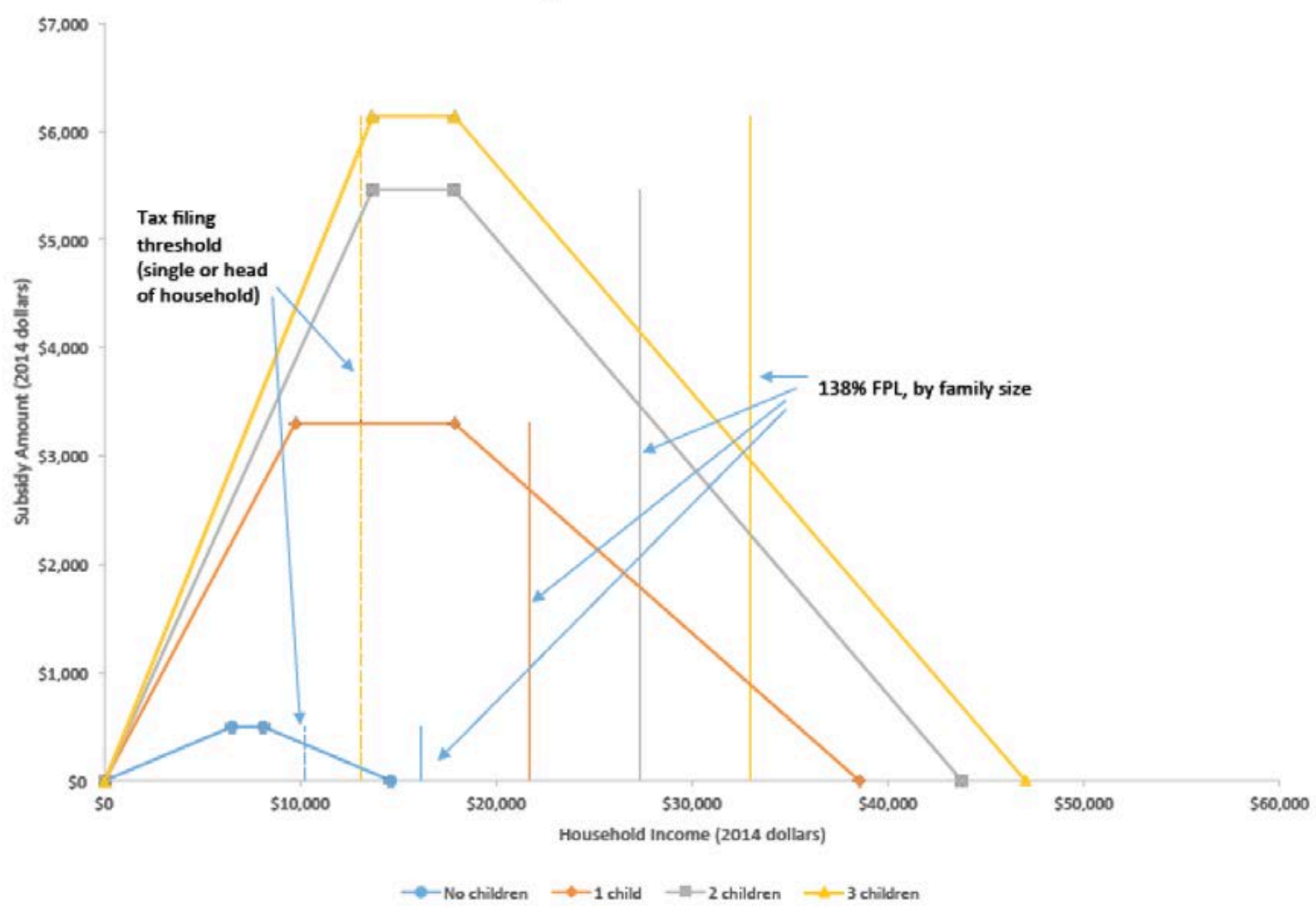


Figure 1b: EITC Schedule for Married Couple Families

EITC Schedule for Married Couple Families

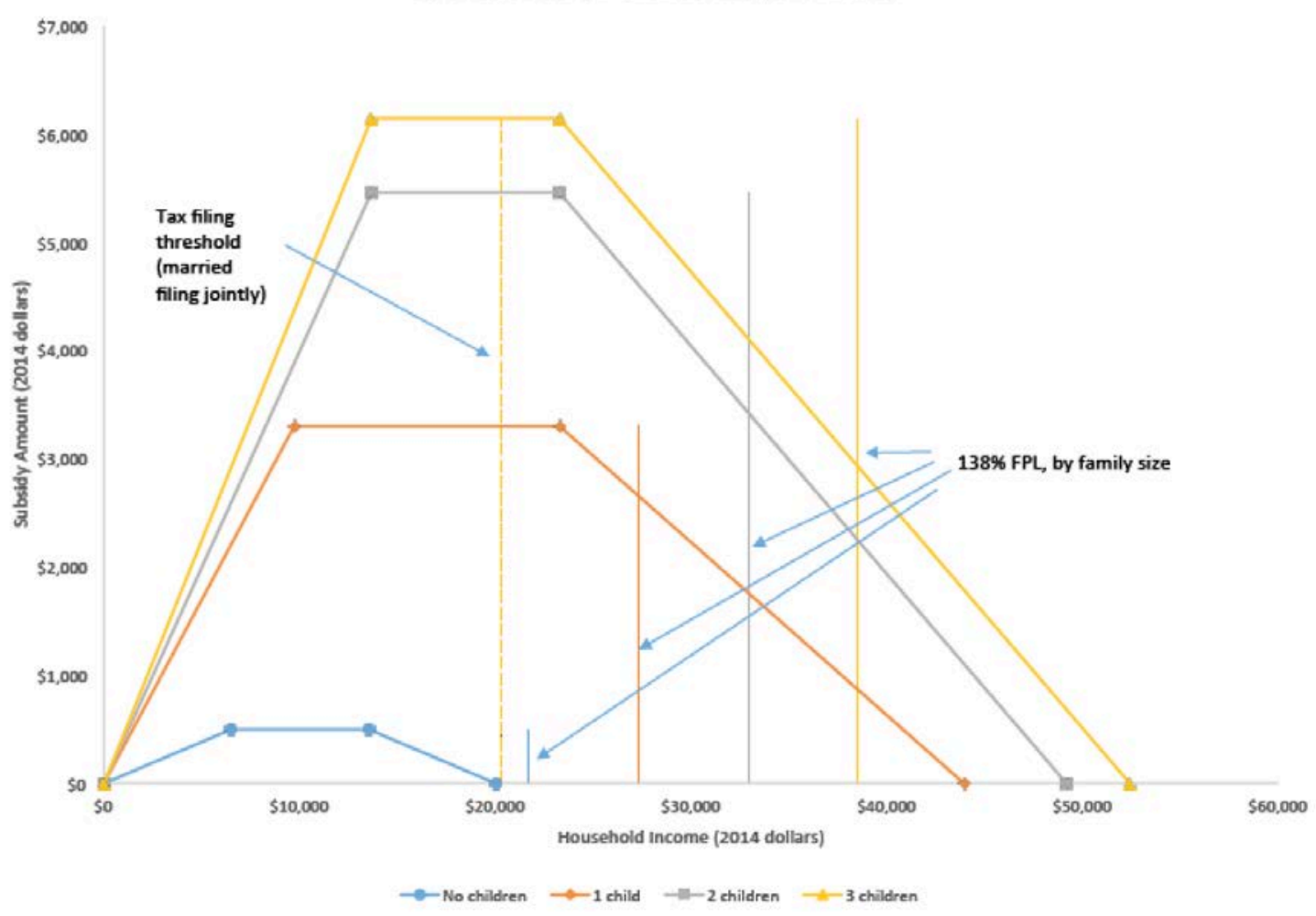


Figure 2: Contiguous Border County Pairs in the US with a Medicaid Expansion Differential, April 2014

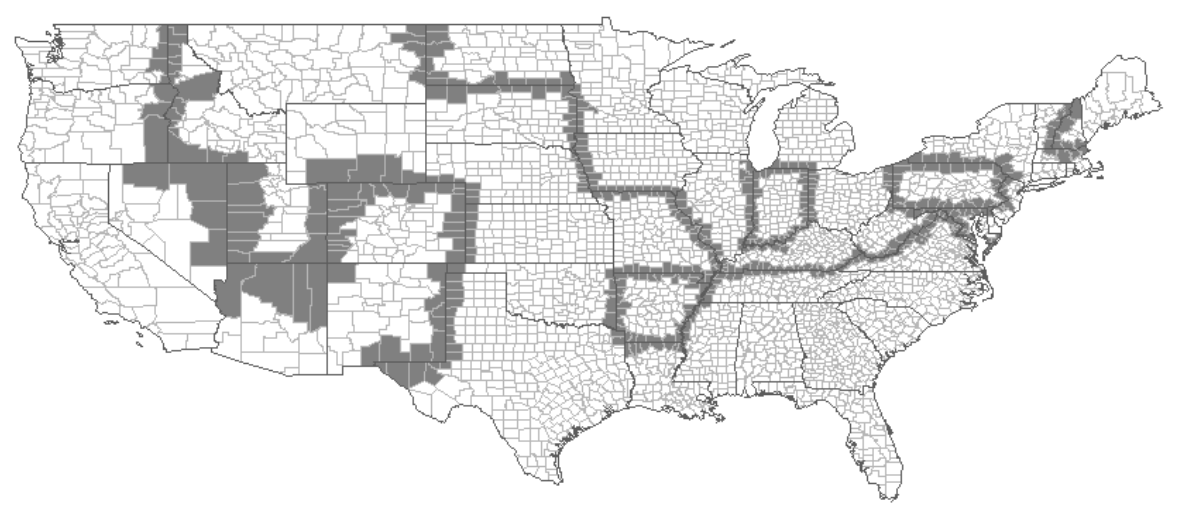

Source: Medicaid expansion status determined from data on state actions collected by the Kaiser Family Foundation. 
Figure 3. Effect of Expansion on Non-categorical Medicaid Income Limit

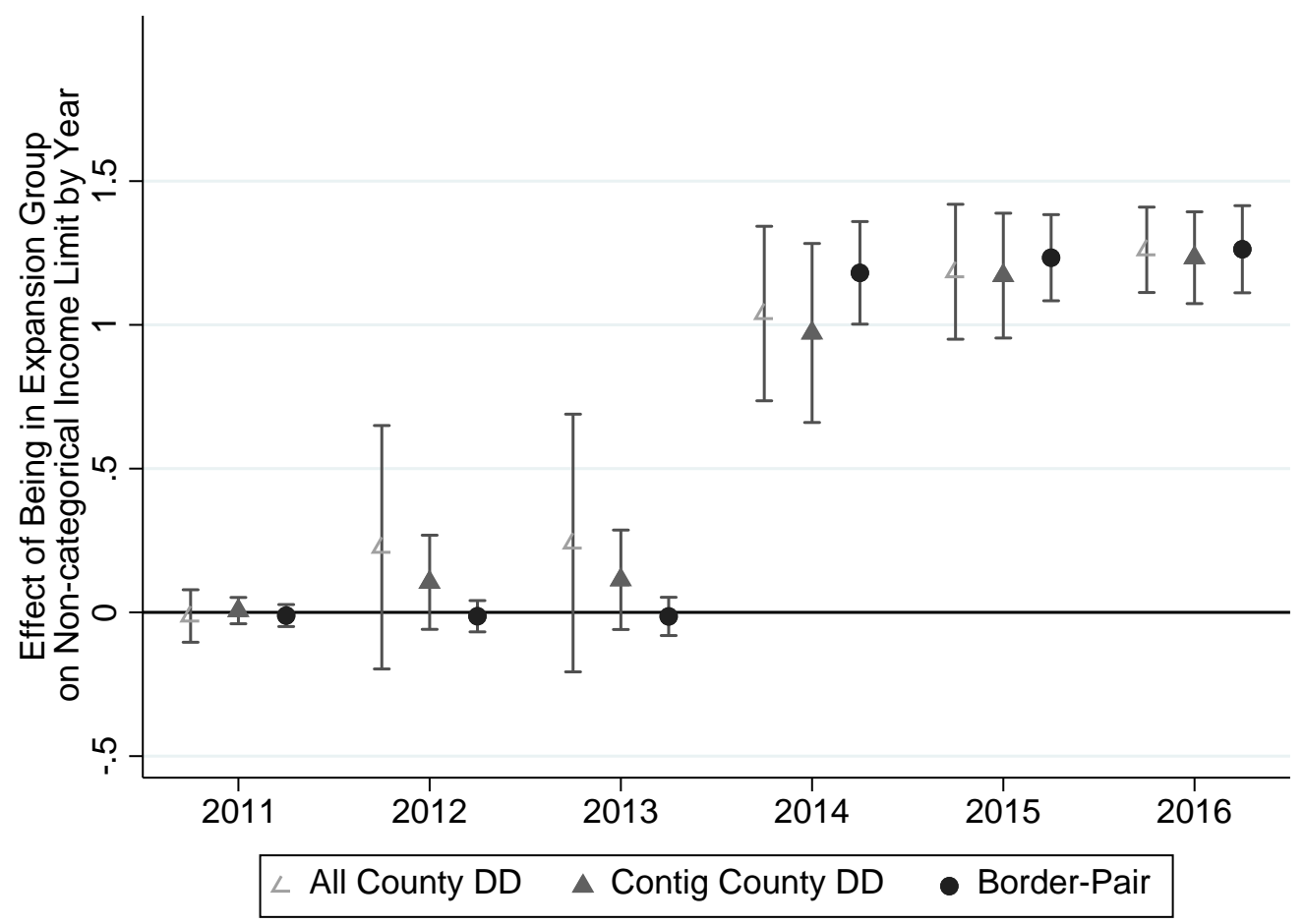

Note: Coefficients from regressions on 2010-2016 data that include county fixed effects and controls for fraction Black and fraction Hispanic. The "Contig County DD” restricts to counties included in the border-pair analysis, and the "Border-Pair" includes border pair by year fixed effects. 
Figure 4. Effect of Expansion on Percent Uninsured

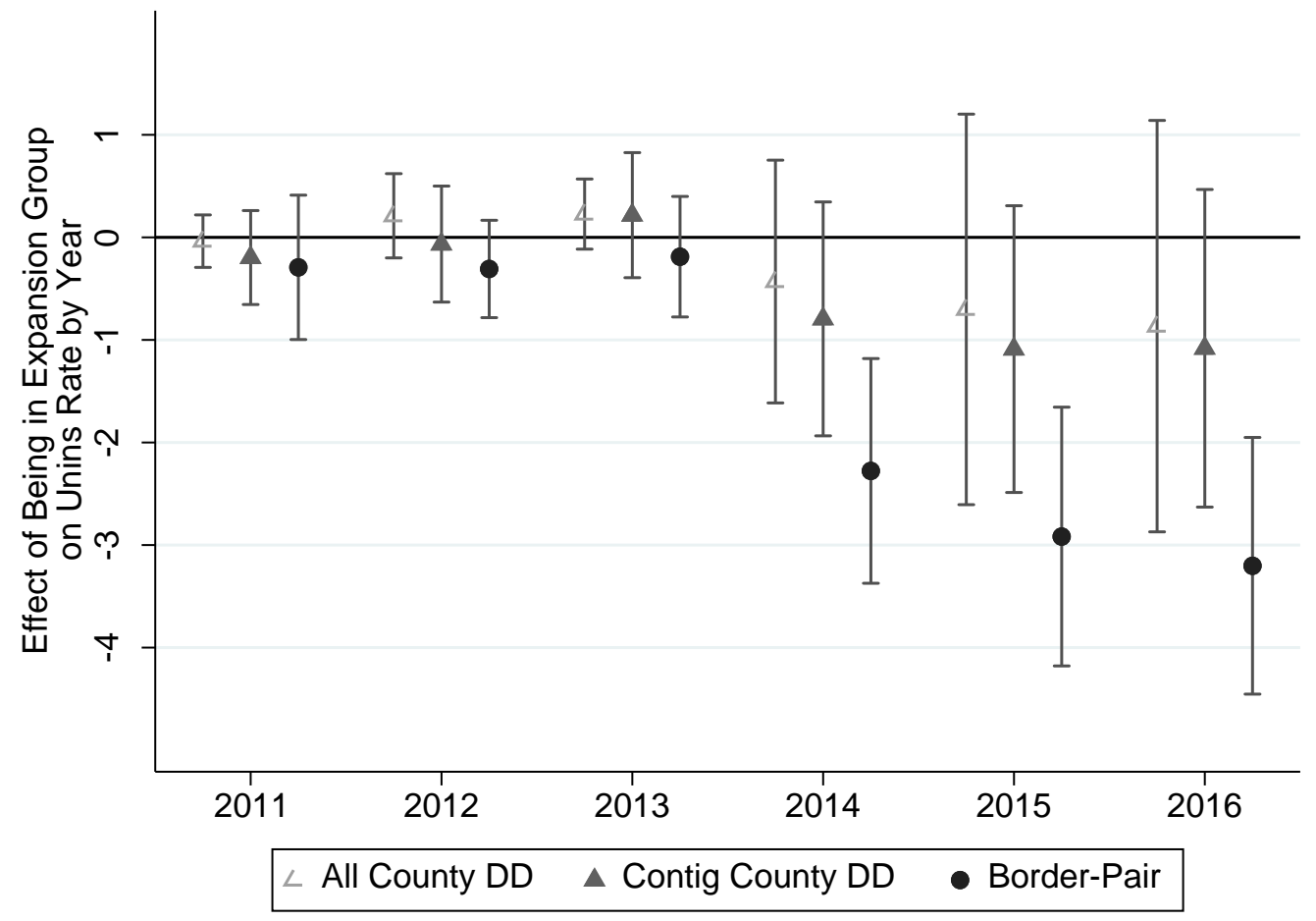


Figure 5. Effect of Expansion on EITC Filing Per 100 Prime-Age Population

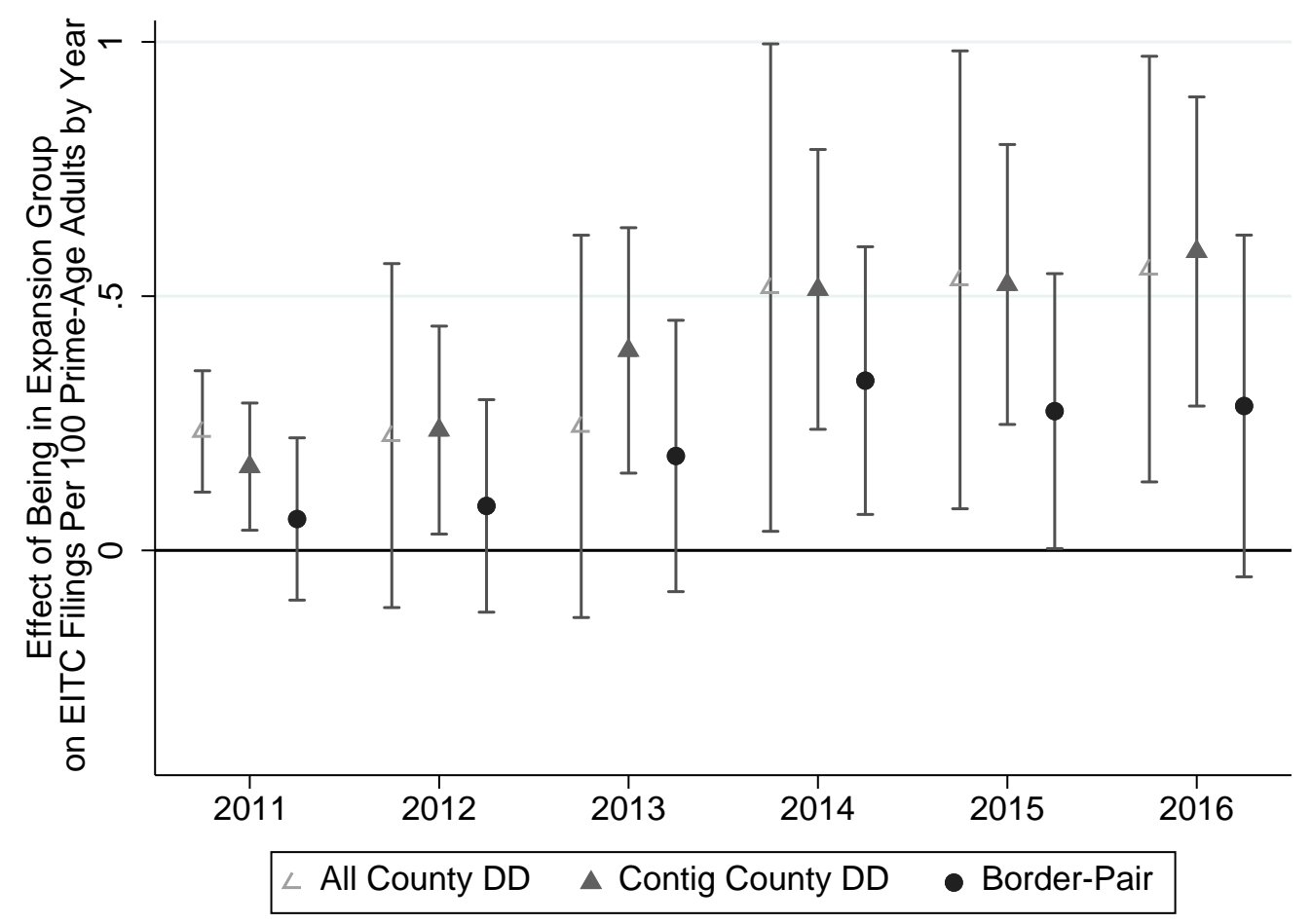

Note: See Figure 3 notes. 
Figure 6. Effect of Expansion on SNAP Participation Rate

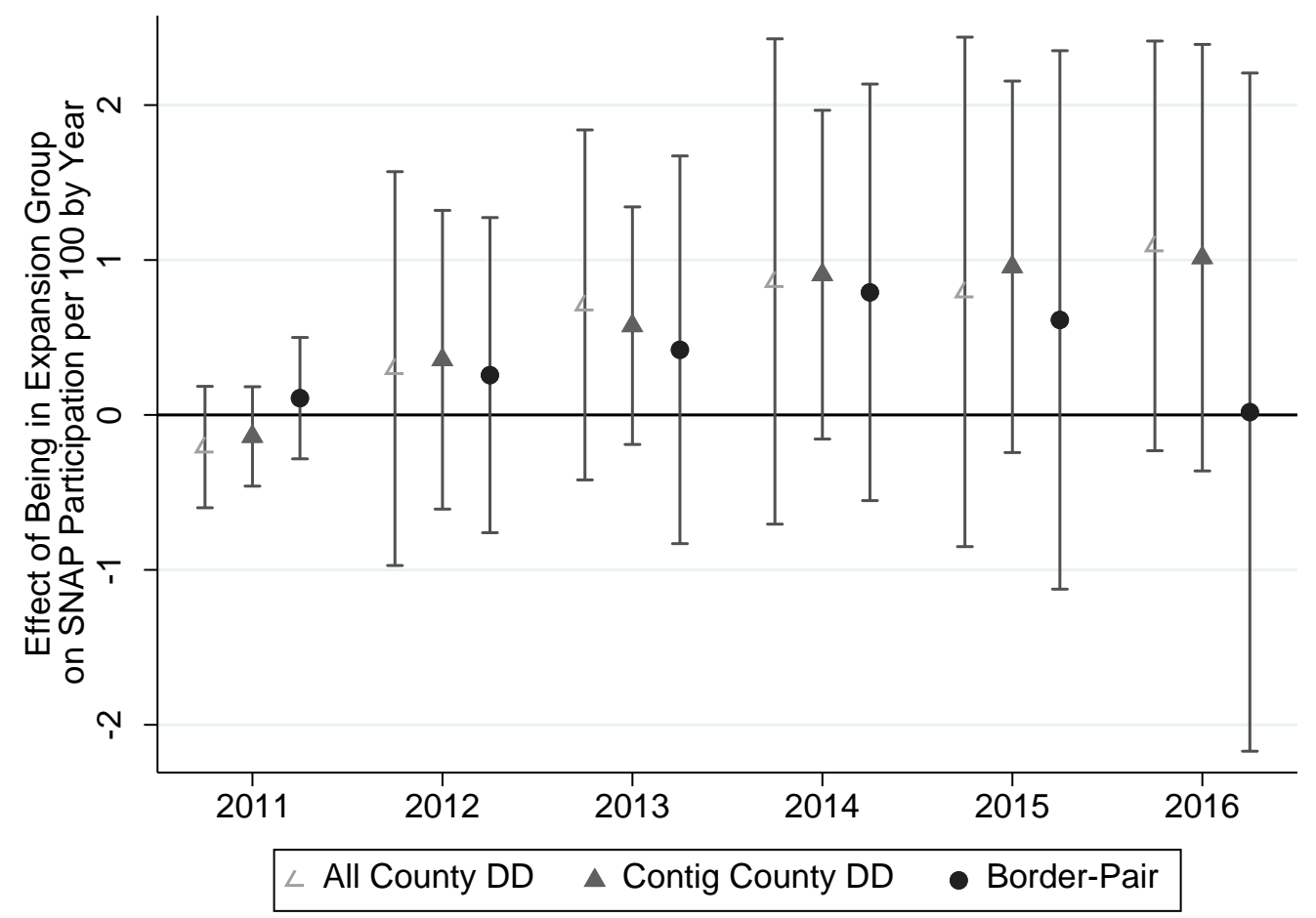

Note: See Figure 3 notes. 
Figure 7. Effect of Expansion on SNAP Participation, ACS data

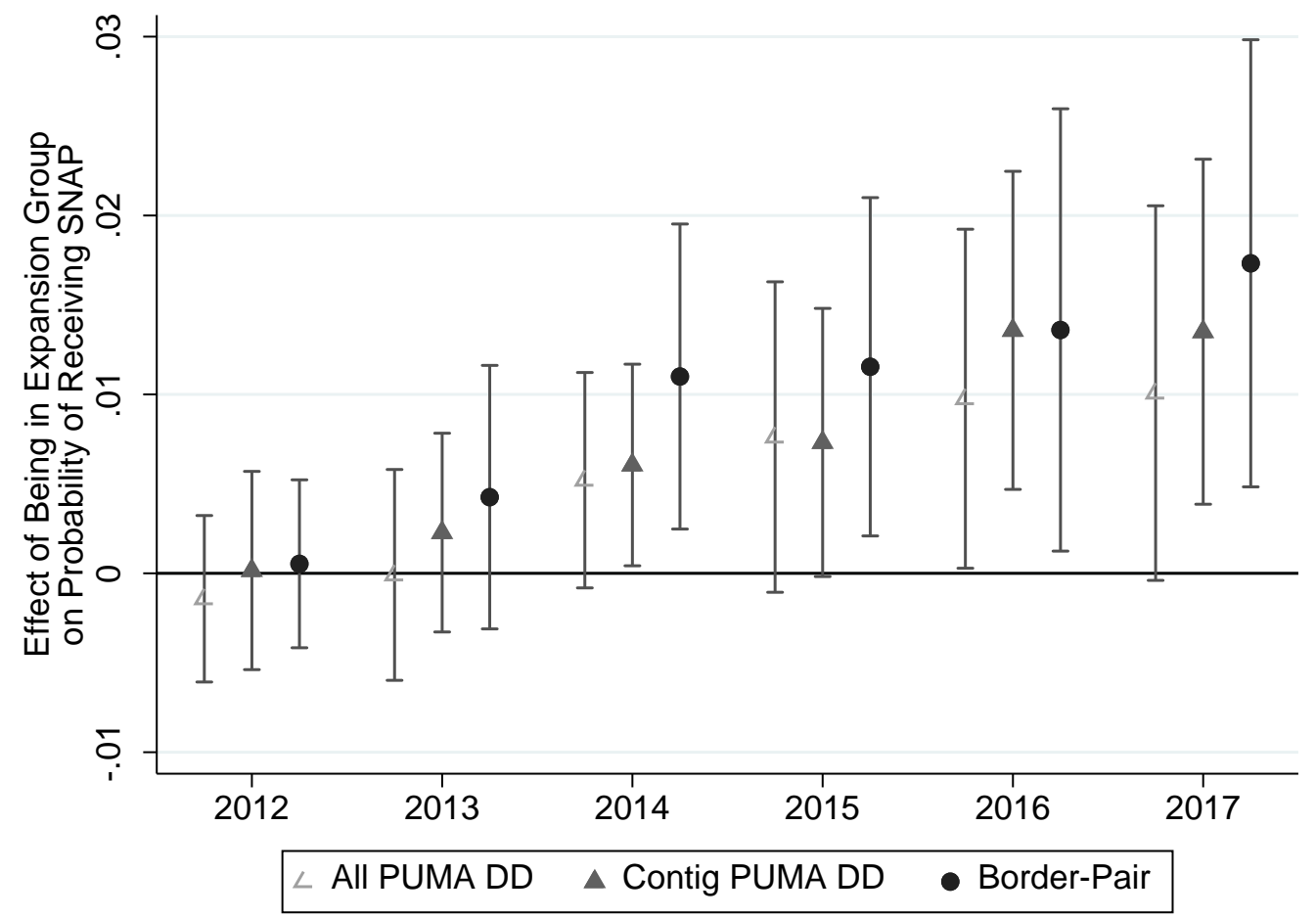


Figure 8: Bacon Decomposition for SNAP County-Level Participation

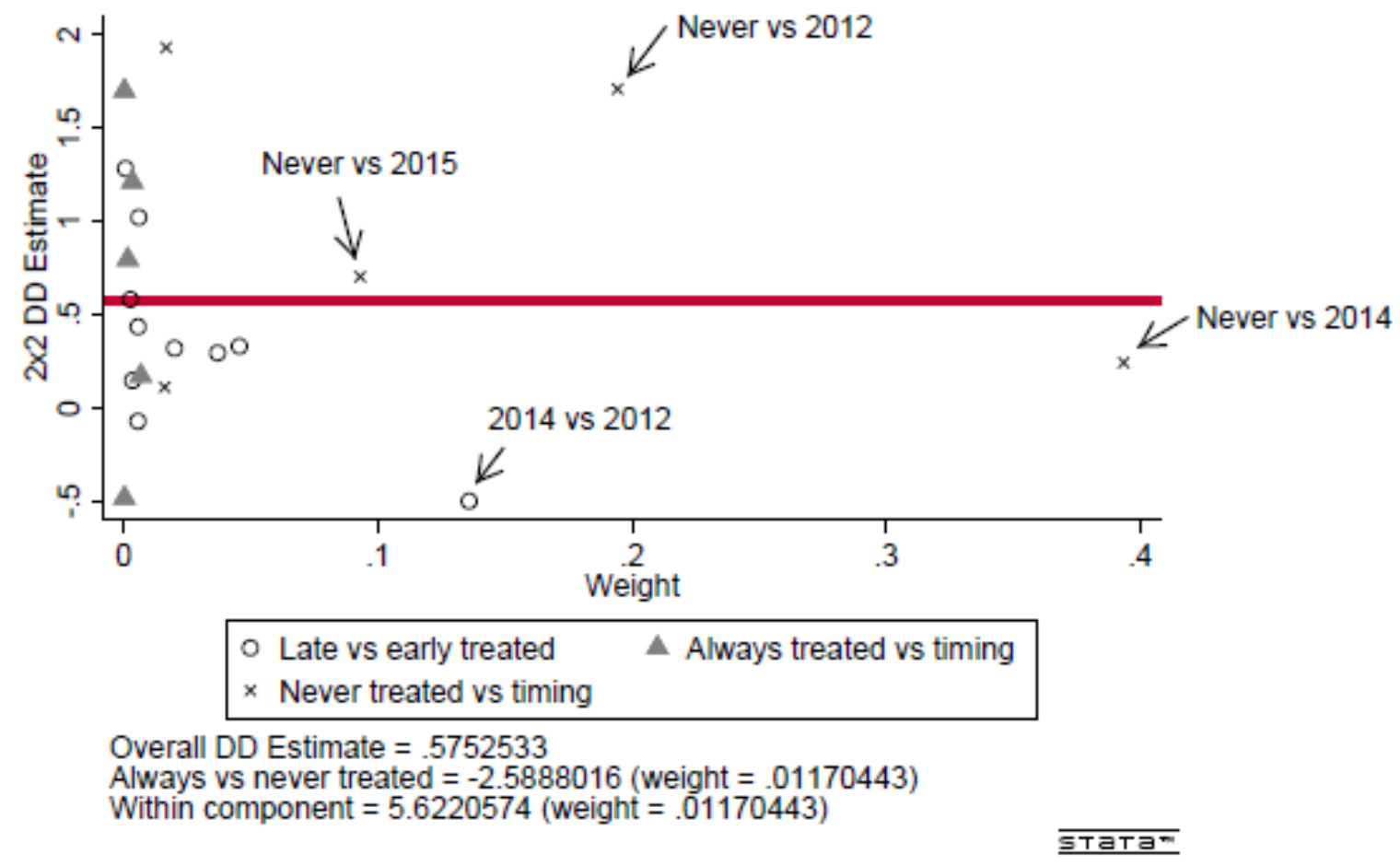


Table 1A: Summary Statistics, All Counties EITC and SNAP Samples 2010-2016

\begin{tabular}{|c|c|c|c|c|}
\hline Variable & Mean & $\begin{array}{c}\text { Standard } \\
\text { Deviation }\end{array}$ & Min & Max \\
\hline \multicolumn{5}{|l|}{$\begin{array}{l}\text { Panel A: EITC Sample, weighted by } \\
\text { working-age population }(N=21,623)\end{array}$} \\
\hline EITC returns per 100 working age adults & 14.229 & 4.591 & 0.0 & 51.6 \\
\hline Percent Uninsured & 14.686 & 6.166 & 2.1 & 41.4 \\
\hline Percent Low-Income Uninsured & 23.350 & 8.219 & 4.5 & 51.2 \\
\hline ACA Medicaid expansion (Y/N) & 0.368 & 0.482 & 0.0 & 1.0 \\
\hline $\begin{array}{l}\text { Medicaid non-categorical income limit } \\
\text { (relative to the poverty line) }\end{array}$ & 0.477 & 0.655 & 0.0 & 2.2 \\
\hline Percent non-Hispanic Black & 13.455 & 12.902 & 0.0 & 86.0 \\
\hline Percent Hispanic & 17.228 & 16.752 & 0.0 & 96.3 \\
\hline \multicolumn{5}{|l|}{$\begin{array}{l}\text { Panel B: SNAP Sample, weighted by total } \\
\text { population }(N=16,965)\end{array}$} \\
\hline SNAP participation rate & 14.374 & 6.514 & 0.0 & 154.6 \\
\hline Percent Uninsured & 15.557 & 6.180 & 2.9 & 41.4 \\
\hline Percent Low-Income Uninsured & 24.503 & 8.059 & 6.2 & 51.2 \\
\hline ACA Medicaid expansion (Y/N) & 0.306 & 0.461 & 0.0 & 1.0 \\
\hline $\begin{array}{l}\text { Medicaid non-categorical income limit } \\
\text { (relative to the poverty line) }\end{array}$ & 0.404 & 0.634 & 0.0 & 2.2 \\
\hline Percent non-Hispanic Black & 14.363 & 13.410 & 0.0 & 86.0 \\
\hline Percent Hispanic & 18.416 & 17.870 & 0.2 & 96.3 \\
\hline
\end{tabular}

Notes: Observations are county-years. See text for sources. 
Table 1B: Weighted Means by Sub-Sample and Year

\begin{tabular}{|c|c|c|c|c|}
\hline Sample and Year & $\begin{array}{c}\text { All Counties } \\
\text { EITC } \\
\text { Sample }\end{array}$ & $\begin{array}{l}\text { Border } \\
\text { Counties } \\
\text { EITC } \\
\text { Sample }\end{array}$ & $\begin{array}{c}\text { All Counties } \\
\text { SNAP } \\
\text { Sample }\end{array}$ & $\begin{array}{l}\text { Border } \\
\text { Counties } \\
\text { SNAP } \\
\text { Sample }\end{array}$ \\
\hline \multicolumn{5}{|l|}{ Panel A: 2010 data } \\
\hline $\begin{array}{l}\text { EITC returns per } 100 \text { working age } \\
\text { adults or SNAP participation rate }\end{array}$ & 12.959 & 12.551 & 14.170 & 14.565 \\
\hline Fraction Uninsured & 17.685 & 15.974 & 18.673 & 17.268 \\
\hline Fraction Low-Income Uninsured & 28.257 & 26.232 & 29.528 & 27.741 \\
\hline ACA Medicaid expansion (Y/N) & 0.125 & 0.157 & 0.032 & 0.032 \\
\hline $\begin{array}{l}\text { Medicaid non-parent income limit } \\
\text { (relative to the poverty line) }\end{array}$ & 0.128 & 0.62 & 0.038 & 0.043 \\
\hline Percent non-Hispanic Black & 13.278 & 13.734 & 14.167 & 15.649 \\
\hline Percent Hispanic & 16.454 & 12.750 & 17.640 & 13.794 \\
\hline Observations & 3089 & 2390 & 2466 & 1781 \\
\hline Unique counties & 3089 & 1138 & 2466 & 859 \\
\hline \multicolumn{5}{|l|}{ Panel B: 2016 data } \\
\hline $\begin{array}{l}\text { EITC returns per } 100 \text { working age } \\
\text { adults or SNAP participation rate }\end{array}$ & 14.235 & 13.919 & 13.254 & 13.929 \\
\hline Fraction Uninsured & 9.965 & 8.903 & 10.675 & 9.699 \\
\hline Fraction Low-Income Uninsured & 15.960 & 14.613 & 16.947 & 15.592 \\
\hline ACA Medicaid expansion (Y/N) & 0.618 & 0.694 & 0.577 & 0.673 \\
\hline $\begin{array}{l}\text { Medicaid non-parent income limit } \\
\text { (relative to the poverty line) }\end{array}$ & 0.902 & 1.005 & 0.804 & 0.944 \\
\hline Percent non-Hispanic Black & 13.163 & 14.076 & 14.535 & 16.008 \\
\hline Percent Hispanic & 18.000 & 14.249 & 19.169 & 15.592 \\
\hline Observations & 3089 & 2390 & 2399 & 1713 \\
\hline Unique counties & 3089 & 1138 & 2399 & 833 \\
\hline
\end{tabular}


Table 1C: Summary Statistics for American Community Survey (2011-2017)

\begin{tabular}{lcccc} 
Variable & Mean & $\begin{array}{c}\text { Standard } \\
\text { Deviation }\end{array}$ & Min & Max \\
\hline Any Health Insurance & 0.87 & 0.34 & 0 & 1 \\
Any SNAP & 0.14 & 0.35 & 0 & 1 \\
Under 130 Pct Poverty & 0.23 & 0.42 & 0 & 1 \\
Imputed EITC Eligibility & 0.15 & 0.35 & 0 & 1 \\
Age & 45.15 & 11.49 & 25 & 64 \\
Female & 0.51 & 0.50 & 0 & 1 \\
Education High School & 0.38 & 0.49 & 0 & 1 \\
Education Some College & 0.26 & 0.44 & 0 & 1 \\
Education College+ & 0.29 & 0.45 & 0 & 1 \\
Non-Hispanic Black & 0.12 & 0.32 & 0 & 1 \\
Hispanic & 0.06 & 0.23 & 0 & 1 \\
Observations & & & &
\end{tabular}


Table 2: Mean Absolute Difference Between Counties in All Pairs and Contiguous Border Pairs Pre-ACA, EITC Sample

\begin{tabular}{lccc}
\hline $\begin{array}{l}\text { Mean Absolute Difference } \\
\text { Between Counties }\end{array}$ & All Pairs & $\begin{array}{c}\text { Contiguous Border } \\
\text { Pairs }\end{array}$ & Difference \\
\hline EITC returns per 100 & $5.343^{* * *}$ & $3.124^{* * *}$ & $-2.219 * * *$ \\
Working Age Adults & $(0.101)$ & $(0.099)$ & $(0.091)$ \\
Non-categorical & $0.100^{* * *}$ & $0.091^{* * *}$ & -0.009 \\
Income Limit & $(0.010)$ & $(0.013)$ & $(0.009)$ \\
Unemployment rate & $3.465^{* * *}$ & $1.881^{* * *}$ & $-1.585^{* * *}$ \\
& $(0.046)$ & $(0.048)$ & $(0.058)$ \\
Percent in poverty & & & $-2.566^{* * *}$ \\
& $\left(0.852^{* * *}\right.$ & $4.287^{* * *}$ & $(0.125)$ \\
Percent non-Hispanic Black & $12.770^{* * *}$ & $(0.129)$ & $-7.787^{* * *}$ \\
& $(0.367)$ & $4.986^{* * *}$ & $(0.287)$ \\
Percent Hispanic & $9.627^{* * *}$ & $(0.252)$ & $-5.465^{* * *}$ \\
& $(0.313)$ & $4.163^{* * *}$ & $(0.256)$ \\
\hline
\end{tabular}

The first column shows the mean absolute difference between pairs formed by matching each county in the 2010 contiguous border county sample with all possible other counties. The second column shows the mean absolute difference in the values of the variables between counties in a contiguous pair in the 2010 data. The symbol *** indicates that the mean absolute difference within county pairs is different from 0 at $\mathrm{p}<0.01$ in columns (1) and (2). The third column represents the difference between columns (1) and (2), and *** indicates the difference between columns (1) and (2) is statistically different from 0 at $\mathrm{p}<0.01$. 
Table 3: Effects of ACA Medicaid Income Limits on Percent Uninsured and Low Income Uninsured

\begin{tabular}{|c|c|c|c|c|c|c|}
\hline & $\begin{array}{c}\text { (1) } \\
\text { All Counties } \\
\text { Sample }\end{array}$ & $\begin{array}{c}(2) \\
\text { Contig } \\
\text { Counties } \\
\text { Sample }\end{array}$ & $\begin{array}{c}(3) \\
\text { Contig } \\
\text { Counties } \\
\text { Sample }\end{array}$ & $\begin{array}{c}(4) \\
\text { All Counties } \\
\text { Sample }\end{array}$ & $\begin{array}{c}(5) \\
\text { Contig } \\
\text { Counties } \\
\text { Sample }\end{array}$ & $\begin{array}{c}(6) \\
\text { Contig } \\
\text { Counties } \\
\text { Sample }\end{array}$ \\
\hline & $\begin{array}{l}\text { Percent } \\
\text { Uninsured }\end{array}$ & $\begin{array}{c}\text { Percent } \\
\text { Uninsured }\end{array}$ & $\begin{array}{c}\text { Percent } \\
\text { Uninsured } \\
\end{array}$ & $\begin{array}{c}\text { Percent } \\
\text { Low-Income } \\
\text { Uninsured }\end{array}$ & $\begin{array}{c}\text { Percent } \\
\text { Low-Income } \\
\text { Uninsured }\end{array}$ & $\begin{array}{c}\text { Percent } \\
\text { Low-Income } \\
\text { Uninsured }\end{array}$ \\
\hline Non-categorical & $-0.566^{* *}$ & $-1.270 * * *$ & $-1.620 * * *$ & $-1.475^{* * *}$ & $-2.382 * * *$ & $-2.778 * * *$ \\
\hline Income Limit & $(0.277)$ & $(0.446)$ & $(0.326)$ & $(0.454)$ & $(0.608)$ & $(0.591)$ \\
\hline $\begin{array}{l}\text { Percent Non- } \\
\text { Hispanic Black }\end{array}$ & $\begin{array}{l}0.889^{*} \\
(0.451)\end{array}$ & $\begin{array}{l}0.631^{*} \\
(0.365)\end{array}$ & $\begin{array}{c}0.341^{* * *} \\
(0.127)\end{array}$ & $\begin{array}{c}0.476 \\
(0.666)\end{array}$ & $\begin{array}{c}0.109 \\
(0.439)\end{array}$ & $\begin{array}{l}-0.390 \\
(0.282)\end{array}$ \\
\hline Percent Hispanic & $\begin{array}{l}-0.441 \\
(0.378)\end{array}$ & $\begin{array}{l}-0.154 \\
(0.748)\end{array}$ & $\begin{array}{l}-0.058 \\
(0.269)\end{array}$ & $\begin{array}{l}-0.319 \\
(0.522)\end{array}$ & $\begin{array}{l}-0.225 \\
(0.861)\end{array}$ & $\begin{array}{c}0.317 \\
(0.507)\end{array}$ \\
\hline Observations & 21,623 & 16,730 & 16,730 & 21,623 & 16,730 & 16,730 \\
\hline R-squared & 0.959 & 0.952 & 0.993 & 0.955 & 0.952 & 0.989 \\
\hline County FE & YES & YES & YES & YES & YES & YES \\
\hline Year FE & YES & YES & NO & YES & YES & NO \\
\hline County Pair*Year FE & NO & NO & YES & NO & NO & YES \\
\hline
\end{tabular}

Dependent variable is the percent of individuals overall or percent of individuals with family incomes under 250 percent of poverty uninsured in a county from the Small Area Health Insurance Estimates 2010-2016. EITC analysis sample is used and excludes Republic County, Kansas. Robust standard errors clustered on state in parentheses. ${ }^{* * *} \mathrm{p}<0.01,{ }^{* *} \mathrm{p}<0.05,{ }^{*} \mathrm{p}<0.1$. 
Table 4: Effects of ACA Medicaid Income Limits on EITC Returns per 100 Working Age Adults

\begin{tabular}{lccc}
\hline & $(1)$ & $(2)$ & $(3)$ \\
& $\begin{array}{c}\text { All Counties } \\
\text { Sample }\end{array}$ & $\begin{array}{c}\text { Contig } \\
\text { Counties } \\
\text { Sample }\end{array}$ & $\begin{array}{c}\text { Contig } \\
\text { Counties } \\
\text { Sample }\end{array}$ \\
\hline Non-categorical & $0.168^{* *}$ & $0.171^{* * *}$ & 0.088 \\
Income Limit & $(0.081)$ & $(0.051)$ & $(0.053)$ \\
Percent Non- & 0.088 & $0.216^{* * *}$ & $0.266^{* * *}$ \\
$\quad$ Hispanic Black & $(0.107)$ & $(0.080)$ & $(0.062)$ \\
Percent Hispanic & $0.163^{* * *}$ & $0.163^{*}$ & $0.154^{*}$ \\
& $(0.053)$ & $(0.084)$ & $(0.084)$ \\
& & & \\
Observations & 21,623 & 16,730 & 16,730 \\
R-squared & 0.990 & 0.993 & 0.998 \\
County FE & YES & YES & YES \\
Year FE & YES & YES & NO \\
County Pair*Year FE & NO & NO & YES \\
\hline
\end{tabular}

Dependent variable is the number of EITC returns*100 in a county divided by number of workingage adults (ages 20-64) in the county. Republic County, Kansas does not appear in the Statistics of Income county data. Estimates are weighted by working-age population. Robust standard errors clustered on state in parentheses. ${ }^{* * *} \mathrm{p}<0.01,{ }^{* *} \mathrm{p}<0.05,{ }^{*} \mathrm{p}<0.1$. 
Table 5: Effects of ACA Medicaid Income Limits on SNAP Participants per 100 People

\begin{tabular}{lccc}
\hline & $\begin{array}{c}(1) \\
\text { All Counties } \\
\text { Sample }\end{array}$ & $\begin{array}{c}(2) \\
\text { Contig } \\
\text { Counties } \\
\text { Sample }\end{array}$ & $\begin{array}{c}(3) \\
\text { Contig } \\
\text { Counties } \\
\text { Sample }\end{array}$ \\
\hline Non-categorical & 0.378 & $0.510^{*}$ & $0.433^{* *}$ \\
Income Limit & $(0.255)$ & $(0.282)$ & $(0.189)$ \\
Percent Non- & 0.006 & $0.471^{* *}$ & $0.776^{* * *}$ \\
$\quad$ Hispanic Black & $(0.216)$ & $(0.204)$ & $(0.230)$ \\
Percent Hispanic & $0.665^{* * *}$ & $1.030^{* * *}$ & 0.453 \\
& $(0.181)$ & $(0.220)$ & $(0.372)$ \\
Observations & 16,965 & 12,197 & 12,197 \\
R-squared & 0.948 & 0.962 & 0.990 \\
County FE & YES & YES & YES \\
Year FE & YES & YES & NO \\
County Pair*Year FE & NO & NO & YES \\
\hline
\end{tabular}

Dependent variable is the number of SNAP participants*100 in a county divided by county population. A number of states do not report county level SNAP data and are excluded from the sample; see text for details. Estimates are weighted by population. Robust standard errors clustered on state in parentheses. ${ }^{* * *} \mathrm{p}<0.01,{ }^{* *} \mathrm{p}<0.05,{ }^{*} \mathrm{p}<0.1$. 
Table 6: State-Level and County-Level Analyses of EITC and SNAP

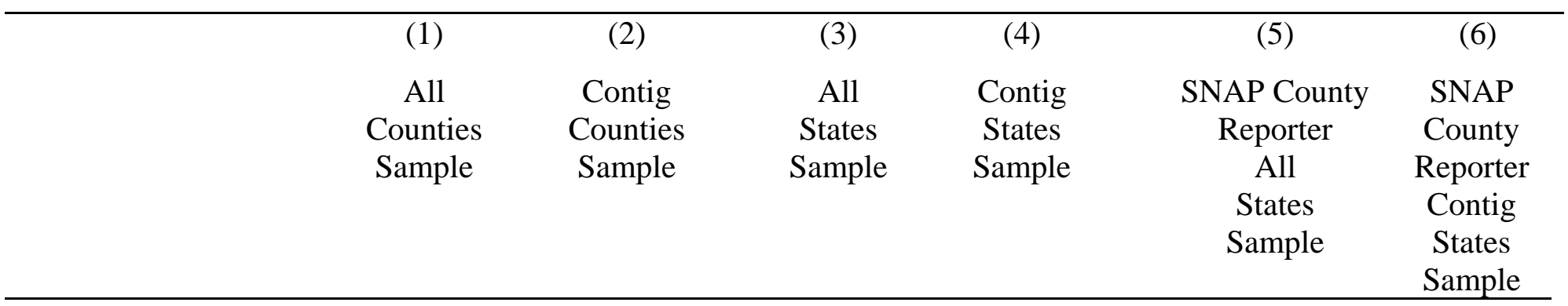

Panel A. Effect of Non-parent Income Limit on EITC Returns per 100 Working-Age Adults

$\begin{array}{lcccc}\text { Non-categorical } & 0.168 * * & 0.088 & 0.194 * * & 0.043 \\ \text { Income Limit } & (0.081) & (0.053) & (0.095) & (0.056) \\ & & & & \\ \text { Observations } & 21,623 & 16,730 & 343 & 1,498\end{array}$

Panel B. Effect of Income Limit for Non-parents on SNAP Participants per 100 People

$\begin{array}{lcccccc}\text { Non-categorical } & 0.378 & 0.433^{* *} & 0.518^{*} & 0.380^{*} & 0.573^{*} & 0.311 \\ \text { Income Limit } & (0.255) & (0.189) & (0.268) & (0.201) & (0.301) & (0.289) \\ \text { Observations } & 16,965 & 12,197 & 342 & 1,496 & 231 & 1,022 \\ & & & & & \text { YES } & \text { YES } \\ \text { County or State FE } & \text { YES } & \text { YES } & \text { YES } & \text { YES } & \text { YES } & \text { NO } \\ \text { Year FE } & \text { YES } & \text { NO } & \text { YES } & \text { NO } & \text { NO } & \text { YES } \\ \text { Pair*Year FE } & \text { NO } & \text { YES } & \text { NO } & \text { YES }\end{array}$

Each cell represents the coefficient on the non-categorical Medicaid income limit from a separate regression. Dependent variable is the number of EITC returns*100 divided by working-age adults or SNAP participants*100 divided by population. EITC state regressions include contiguous 48 states plus D.C.; some state-years are missing. SNAP “county reporter” state regressions further exclude 14 states that do not report county-level SNAP data. Race/ethnicity controls included. Estimates are weighted by working-age population or population. Robust standard errors clustered on state in parentheses. ${ }^{* * *} \mathrm{p}<0.01,{ }^{* *} \mathrm{p}<0.05,{ }^{*} \mathrm{p}<0.1$. 
Table 7. Health Insurance and Safety Net Outcomes in the ACS

\begin{tabular}{|c|c|c|c|c|c|}
\hline & (1) & (2) & (3) & (4) & (5) \\
\hline & All & Non-Parents $<50$ & Non-Parents 50+ & Single Parents & Married Parents \\
\hline & $(\mathrm{N}=20,267,758)$ & $(\mathrm{N}=4,732,326)$ & $(\mathrm{N}=8,127,240)$ & $(\mathrm{N}=1,652,339)$ & $(\mathrm{N}=5,755,853)$ \\
\hline \multirow[t]{3}{*}{ Any Health Ins } & $0.0197 * * *$ & $0.0289 * * *$ & $0.0163 * * *$ & $0.0301 * * *$ & $0.0119 * * *$ \\
\hline & $(0.003)$ & $(0.004)$ & $(0.002)$ & $(0.006)$ & $(0.003)$ \\
\hline & $<0.001>* * *$ & $<0.001>* * *$ & $<0.001>* * *$ & $<0.001>* * *$ & $<0.001>* * *$ \\
\hline Any Health Ins & $0.0595 * * *$ & $0.0766 * * *$ & $0.0579 * * *$ & $0.0464 * * *$ & $0.0475 * * *$ \\
\hline Sample $<130$ Percent & $(0.007)$ & $(0.009)$ & $(0.005)$ & $(0.009)$ & $(0.010)$ \\
\hline of Poverty & $<0.001>* * *$ & $<0.001>* * *$ & $<0.001>* * *$ & $<0.001>* * *$ & $<0.001>* * *$ \\
\hline \multirow[t]{2}{*}{ Public Health Ins } & $\begin{array}{c}0.0293 * * * \\
(0.003)\end{array}$ & $\begin{array}{c}0.0357 * * * \\
(0.004)\end{array}$ & $\begin{array}{c}0.0237 * * * \\
(0.003)\end{array}$ & $\begin{array}{c}0.0486 * * * \\
(0.008)\end{array}$ & $\begin{array}{c}0.0242 * * * \\
(0.004)\end{array}$ \\
\hline & $<0.001>* * *$ & $<0.001>* * *$ & $<0.001>* * *$ & $<0.001>* * *$ & $<0.001>* * *$ \\
\hline \multirow[t]{2}{*}{ Private Health Ins } & $\begin{array}{c}-0.0088 * * * \\
(0.001)\end{array}$ & $\begin{array}{c}-0.0065 * * * \\
(0.002)\end{array}$ & $\begin{array}{c}-0.0076 * * * \\
(0.002)\end{array}$ & $\begin{array}{c}-0.0179 * * * \\
(0.004)\end{array}$ & $\begin{array}{c}-0.0092 * * * \\
(0.003)\end{array}$ \\
\hline & $<0.001>* * *$ & $<0.001>* * *$ & $<0.001>* * *$ & $<0.001>* * *$ & $<0.002>* * *$ \\
\hline \multirow[t]{2}{*}{ Any SNAP } & $\begin{array}{c}0.0087 * * * \\
(0.002)\end{array}$ & $\begin{array}{c}0.0106 * * * \\
(0.002)\end{array}$ & $\begin{array}{c}0.0089 * * * \\
(0.002)\end{array}$ & $\begin{array}{c}0.0096 * \\
(0.005)\end{array}$ & $\begin{array}{c}0.0059 * * \\
(0.002)\end{array}$ \\
\hline & $<0.001>* * *$ & $<0.001>* * *$ & $<0.001>* * *$ & $<0.015>* *$ & $<0.005>* * *$ \\
\hline Any SNAP & $0.0184 * * *$ & $0.0229 * * *$ & $0.0180 * *$ & $0.0128 *$ & $0.0190 *$ \\
\hline Sample<130 Percent & $(0.005)$ & $(0.006)$ & $(0.007)$ & $(0.007)$ & $(0.010)$ \\
\hline of Poverty & $<0.001>* * *$ & $<0.001>* * *$ & $<0.006>* * *$ & $<0.014>* *$ & $<0.014>* *$ \\
\hline SNAP \& Public & $0.0161^{* * *}$ & $0.0180 * * *$ & $0.0133 * * *$ & $0.0297 * * *$ & $0.0130 * * *$ \\
\hline \multirow[t]{2}{*}{ Health Ins } & $(0.002)$ & $(0.003)$ & $(0.002)$ & $(0.006)$ & $(0.002)$ \\
\hline & $<0.001>* * *$ & $<0.001>* * *$ & $<0.001>* * *$ & $<0.001>* * *$ & $<0.001>* * *$ \\
\hline
\end{tabular}




\begin{tabular}{|c|c|c|c|c|c|}
\hline $\begin{array}{c}\text { SNAP \& No Public } \\
\text { Health Ins }\end{array}$ & $\begin{array}{c}-0.0074 * * * \\
(0.002) \\
<0.001>* * *\end{array}$ & $\begin{array}{c}-0.0074 * * * \\
(0.002) \\
<0.001>* * *\end{array}$ & $\begin{array}{c}-0.0044^{* * *} \\
(0.001) \\
<0.001>* * *\end{array}$ & $\begin{array}{c}-0.0201 * * * \\
(0.006) \\
<0.002>* * *\end{array}$ & $\begin{array}{c}-0.0072^{* * *} \\
(0.003) \\
<0.003>* * *\end{array}$ \\
\hline $\begin{array}{c}\text { No SNAP \& Public } \\
\text { Health Ins }\end{array}$ & $\begin{array}{c}0.0132 * * * \\
(0.002) \\
<0.001>* * *\end{array}$ & $\begin{array}{c}0.0177 * * * \\
(0.002) \\
<0.001>* * *\end{array}$ & $\begin{array}{c}0.0104 * * * \\
(0.002) \\
<0.001>* * *\end{array}$ & $\begin{array}{c}0.0189 * * * \\
(0.005) \\
<0.001>* * *\end{array}$ & $\begin{array}{c}0.0112 * * * \\
(0.002) \\
<0.001>* * *\end{array}$ \\
\hline Any TANF & $\begin{array}{c}0.0013 * * \\
(0.001) \\
<0.008>* * *\end{array}$ & $\begin{array}{c}0.0012 \\
(0.001) \\
<0.026>* *\end{array}$ & $\begin{array}{c}0.0003 \\
(0.001) \\
<0.072>*\end{array}$ & $\begin{array}{c}0.0071^{* *} \\
(0.003) \\
<0.004>* * *\end{array}$ & $\begin{array}{c}0.0006^{*} \\
(0.000) \\
<0.018>* *\end{array}$ \\
\hline
\end{tabular}

Notes: Sample is individual citizens ages 25 to 64 in contiguous PUMA pairs from 2011-2017 American Community Survey. Each cell is a coefficient on the state non-categorical income limit for the year prior to survey year from a separate regression. Analyses include PUMA fixed effects, PUMA-pair-year fixed effects, and controls for demographic group interacted with Black, demographic group interacted with Hispanic, female, age, age squared, education high school, education some college, and education college grad. Parental status defined by whether a parent reports a child in the household under 19 is their own biological, step, or adoptive child or that of their partner. Robust standard errors clustered on state in parentheses. For coefficients, asterisks reflect p-values associated with the robust standard errors. ${ }^{* * *} \mathrm{p}<0.01,{ }^{* *} \mathrm{p}<0.05,{ }^{*} \mathrm{p}<0.1$. False discovery rate $\mathrm{q}$-values and associated asterisks are shown in brackets. ${ }^{* * *} \mathrm{q}<0.01,{ }^{* *} \mathrm{q}<0.05,{ }^{*} \mathrm{q}<0.1$. 
Table 8. Income and Labor Market Outcomes in the ACS

\begin{tabular}{|c|c|c|c|c|c|}
\hline & $\begin{array}{c}(1) \\
\text { All } \\
(\mathrm{N}=20,267,758)\end{array}$ & $\begin{array}{c}(2) \\
\text { Non-Parents }<50 \\
(\mathrm{~N}=4,732,326)\end{array}$ & $\begin{array}{c}(3) \\
\text { Non-Parents 50+ } \\
(\mathrm{N}=8,127,240)\end{array}$ & $\begin{array}{c}(4) \\
\text { Single Parents } \\
(\mathrm{N}=1,652,339)\end{array}$ & $\begin{array}{c}(5) \\
\text { Married Parents } \\
(\mathrm{N}=5,755,853)\end{array}$ \\
\hline Imputed EITC Eligibility & $\begin{array}{c}0.0022^{* *} \\
(0.001) \\
<0.189>\end{array}$ & $\begin{array}{l}0.0000 \\
(0.001) \\
<0.899>\end{array}$ & $\begin{array}{c}0.0019 * * \\
(0.001) \\
<0.189>\end{array}$ & $\begin{array}{c}0.0056 * \\
(0.003) \\
<0.447>\end{array}$ & $\begin{array}{l}0.0036 \\
(0.002) \\
<0.447>\end{array}$ \\
\hline Under 130 Percent of Poverty & $\begin{array}{c}0.0014 \\
(0.001) \\
<0.447>\end{array}$ & $\begin{array}{l}-0.0020 \\
(0.002) \\
<0.605>\end{array}$ & $\begin{array}{c}0.0030 * * \\
(0.001) \\
<0.189>\end{array}$ & $\begin{array}{l}-0.0054 \\
(0.003) \\
<0.447>\end{array}$ & $\begin{array}{c}0.0038 \\
(0.002) \\
<0.447>\end{array}$ \\
\hline Under 50 Percent of Poverty & $\begin{array}{c}0.0019 * * \\
(0.001) \\
<0.201>\end{array}$ & $\begin{array}{l}0.0024 \\
(0.002) \\
<0.451>\end{array}$ & $\begin{array}{c}0.0013 \\
(0.001) \\
<0.447>\end{array}$ & $\begin{array}{l}-0.0043 \\
(0.003) \\
<0.447>\end{array}$ & $\begin{array}{c}0.0037 * * \\
(0.002) \\
<0.189>\end{array}$ \\
\hline Any Earnings & $\begin{array}{l}0.0014 \\
(0.001) \\
<0.447>\end{array}$ & $\begin{array}{l}0.0026^{*} \\
(0.001) \\
<0.351>\end{array}$ & $\begin{array}{c}0.0004 \\
(0.002) \\
<0.803>\end{array}$ & $\begin{array}{c}0.0060 * * \\
(0.003) \\
<0.201>\end{array}$ & $\begin{array}{l}0.0002 \\
(0.002) \\
<0.862>\end{array}$ \\
\hline Any Wages & $\begin{array}{l}0.0019 \\
(0.001) \\
<0.447>\end{array}$ & $\begin{array}{l}0.0027 \\
(0.002) \\
<0.447>\end{array}$ & $\begin{array}{l}0.0018 \\
(0.002) \\
<0.605>\end{array}$ & $\begin{array}{c}0.0087 * * * \\
(0.003) \\
<0.084>*\end{array}$ & $\begin{array}{l}-0.0013 \\
(0.002) \\
<0.605>\end{array}$ \\
\hline Any Business Income & $\begin{array}{l}-0.0009 \\
(0.001) \\
<0.447>\end{array}$ & $\begin{array}{c}-0.0024 * * * \\
(0.001) \\
<0.189>\end{array}$ & $\begin{array}{c}-0.0010 \\
(0.001) \\
<0.485>\end{array}$ & $\begin{array}{c}-0.0016 \\
(0.002) \\
<0.605>\end{array}$ & $\begin{array}{c}0.0015 \\
(0.001) \\
<0.447>\end{array}$ \\
\hline Any Usual Hours Worked & $\begin{array}{c}0.0015 \\
(0.001) \\
<0.447>\end{array}$ & $\begin{array}{c}0.0028 * * \\
(0.001) \\
<0.243>\end{array}$ & $\begin{array}{c}0.0003 \\
(0.002) \\
<0.803>\end{array}$ & $\begin{array}{c}0.0064^{* *} \\
(0.003) \\
<0.189>\end{array}$ & $\begin{array}{c}0.0003 \\
(0.002) \\
<0.803>\end{array}$ \\
\hline
\end{tabular}




\begin{tabular}{|c|c|c|c|c|c|}
\hline Full-time Hours & $\begin{array}{c}-0.0005 \\
(0.001) \\
<0.659>\end{array}$ & $\begin{array}{c}0.0052 * * * \\
(0.002) \\
<0.084>*\end{array}$ & $\begin{array}{c}-0.0026 \\
(0.002) \\
<0.447>\end{array}$ & $\begin{array}{c}-0.0012 \\
(0.003) \\
<0.685>\end{array}$ & $\begin{array}{c}-0.0025 \\
(0.003) \\
<0.605>\end{array}$ \\
\hline Number Earners (Self and/or Spouse) & $\begin{array}{c}0.0012 \\
(0.002) \\
<0.605>\end{array}$ & $\begin{array}{c}-0.0002 \\
(0.003) \\
<0.865>\end{array}$ & $\begin{array}{c}0.0022 \\
(0.004) \\
<0.605>\end{array}$ & $\mathrm{n} / \mathrm{a}$ & $\begin{array}{c}0.0009 \\
(0.003) \\
<0.744>\end{array}$ \\
\hline Any Earners (Self or Spouse) & $\begin{array}{c}0.0002 \\
(0.001) \\
<0.744>\end{array}$ & $\begin{array}{c}0.0021 \\
(0.001) \\
<0.447>\end{array}$ & $\begin{array}{c}-0.0012 \\
(0.002) \\
<0.605>\end{array}$ & $\mathrm{n} / \mathrm{a}$ & $\begin{array}{c}-0.0008 \\
(0.001) \\
<0.605>\end{array}$ \\
\hline Any Wages (Self or Spouse) & $\begin{array}{c}0.0008 \\
(0.001) \\
<0.605>\end{array}$ & $\begin{array}{c}0.0021 \\
(0.002) \\
<0.605>\end{array}$ & $\begin{array}{l}-0.0000 \\
(0.002) \\
<0.900>\end{array}$ & $\mathrm{n} / \mathrm{a}$ & $\begin{array}{c}-0.0016 \\
(0.001) \\
<0.605>\end{array}$ \\
\hline $\begin{array}{l}\text { Any Business Income (Self or } \\
\text { Spouse) }\end{array}$ & $\begin{array}{c}-0.0006 \\
(0.001) \\
<0.605>\end{array}$ & $\begin{array}{c}-0.0020 \\
(0.001) \\
<0.447>\end{array}$ & $\begin{array}{c}-0.0007 \\
(0.001) \\
<0.605>\end{array}$ & $\mathrm{n} / \mathrm{a}$ & $\begin{array}{c}0.0023 \\
(0.002) \\
<0.447>\end{array}$ \\
\hline Log(Combined Earnings) & $\begin{array}{c}-0.0060 \\
(0.004) \\
<0.447>\end{array}$ & $\begin{array}{c}-0.0054 \\
(0.006) \\
<0.605>\end{array}$ & $\begin{array}{c}-0.0043 \\
(0.005) \\
<0.605>\end{array}$ & $\begin{array}{c}-0.0052 \\
(0.008) \\
<0.605>\end{array}$ & $\begin{array}{c}-0.0063 \\
(0.006) \\
<0.605>\end{array}$ \\
\hline
\end{tabular}

Notes: Sample is individual citizens ages 25 to 64 in contiguous PUMA pairs from 2011-2017 American Community Survey. Each cell is a coefficient on the state non-categorical income limit for the year prior to survey year from a separate regression. Analyses include PUMA fixed effects, PUMA-pair-year fixed effects, and controls for demographic group interacted with Black, demographic group interacted with Hispanic, female, age, age squared, education high school, education some college, and education college grad. Parental status defined by whether a parent reports a child in the household under 19 is their own biological, step, or adoptive child or that of their partner. Robust standard errors clustered on state in parentheses. For coefficients, asterisks reflect p-values associated with the robust standard errors. ${ }^{* * *} \mathrm{p}<0.01,{ }^{* *} \mathrm{p}<0.05,{ }^{*} \mathrm{p}<0.1$. False discovery rate $\mathrm{q}$-values and associated asterisks are shown in brackets. ${ }^{* * *} \mathrm{q}<0.01,{ }^{* *} \mathrm{q}<0.05$, ${ }^{*} \mathrm{q}<0.1$. 
Table 9. Effect of State and Local Policy Environments on SNAP Spillovers

\begin{tabular}{|c|c|c|c|c|}
\hline $\begin{array}{l}\text { Dependent Variable: Any SNAP } \\
2013 \text { Policy Characteristic: }\end{array}$ & $\begin{array}{l}(1) \\
\text { None } \\
\end{array}$ & $\begin{array}{l}\text { (2) } \\
\text { SNAP } \\
\text { Eligibility } \\
\text { Index } \\
\end{array}$ & $\begin{array}{l}(3) \\
\text { SNAP } \\
\text { Enrollment } \\
\text { Index } \\
\end{array}$ & Unmet Need \\
\hline \multicolumn{5}{|l|}{ Panel A: Full Sample $(\mathrm{N}=9,881,283)$} \\
\hline Non-categorical Income Limit & $\begin{array}{c}0.0045^{* *} \\
(0.002)\end{array}$ & $\begin{array}{c}-0.0129 * * \\
(0.006)\end{array}$ & $\begin{array}{l}0.0016 \\
(0.006)\end{array}$ & $\begin{array}{l}-0.0016 \\
(0.003)\end{array}$ \\
\hline Income Limit X Characteristic & & $\begin{array}{c}0.0091 * * \\
(0.004) \\
<0.005>* * *\end{array}$ & $\begin{array}{l}0.0014 \\
(0.003) \\
<0.463>\end{array}$ & $\begin{array}{l}0.0446^{* * *} \\
\quad(0.013) \\
<0.032>* *\end{array}$ \\
\hline \multicolumn{5}{|c|}{ Panel B. All Under 130 FPL ( $N=1,989,007)$} \\
\hline Non-categorical Income Limit & $\begin{array}{c}0.0117 * * \\
(0.005)\end{array}$ & $\begin{array}{c}-0.0336 * * \\
(0.016)\end{array}$ & $\begin{array}{l}0.0132 \\
(0.014)\end{array}$ & $\begin{array}{l}-0.0027 \\
(0.008)\end{array}$ \\
\hline Income Limit X Characteristic & & $\begin{array}{c}0.0238 * * \\
(0.009) \\
<0.005>* * *\end{array}$ & $\begin{array}{l}-0.0007 \\
(0.006) \\
<0.315>\end{array}$ & $\begin{array}{l}0.1038 * * * \\
(0.032) \\
<0.040>* *\end{array}$ \\
\hline \multicolumn{5}{|c|}{ Panel C. Non-parents Ages 25-49 $(\mathrm{N}=2,572,014)$} \\
\hline Non-categorical Income Limit & $\begin{array}{c}0.0051^{* *} \\
(0.002)\end{array}$ & $\begin{array}{l}-0.0134 \\
(0.011)\end{array}$ & $\begin{array}{l}0.0010 \\
(0.007)\end{array}$ & $\begin{array}{l}-0.0028 \\
(0.004)\end{array}$ \\
\hline Income Limit X Characteristic & & $\begin{array}{c}0.0097 \\
(0.006) \\
<0.064>*\end{array}$ & $\begin{array}{l}0.0020 \\
(0.003) \\
<0.300>\end{array}$ & $\begin{array}{l}0.0560 * * * \\
(0.015) \\
<0.040>* *\end{array}$ \\
\hline \multicolumn{5}{|c|}{ Panel D. Non-Parents 50+ $(\mathrm{N}=3,787,269)$} \\
\hline Non-categorical Income Limit & $\begin{array}{c}0.0059 * * * \\
(0.002)\end{array}$ & $\begin{array}{l}-0.0053 \\
(0.004)\end{array}$ & $\begin{array}{l}0.0032 \\
(0.005)\end{array}$ & $\begin{array}{l}0.0031 \\
(0.003)\end{array}$ \\
\hline Income Limit X Characteristic & & $\begin{array}{c}0.0059 * * \\
(0.003) \\
<0.005>* * *\end{array}$ & $\begin{array}{l}0.0013 \\
(0.002) \\
<0.300>\end{array}$ & $\begin{array}{c}0.0204^{*} \\
(0.011) \\
<0.074>*\end{array}$ \\
\hline \multicolumn{5}{|c|}{ Panel E. Single Parents $(N=815,375)$} \\
\hline Non-categorical Income Limit & $\begin{array}{l}0.0031 \\
(0.006)\end{array}$ & $\begin{array}{c}-0.0313^{* *} \\
(0.013)\end{array}$ & $\begin{array}{c}-0.0026 \\
(0.014)\end{array}$ & $\begin{array}{l}-0.0126 \\
(0.009)\end{array}$ \\
\hline Income Limit X Characteristic & & $\begin{array}{c}0.0180 * * \\
(0.008) \\
<0.006>* * *\end{array}$ & $\begin{array}{l}0.0028 \\
(0.006) \\
<0.463>\end{array}$ & $\begin{array}{l}0.1134 * * * \\
(0.032) \\
<0.028>* *\end{array}$ \\
\hline \multicolumn{5}{|c|}{ Panel F. Married Parents $(\mathrm{N}=2,706,625)$} \\
\hline Non-categorical Income Limit & $\begin{array}{l}0.0020 \\
(0.002)\end{array}$ & $\begin{array}{c}-0.0133^{* *} \\
(0.006)\end{array}$ & $\begin{array}{l}0.0017 \\
(0.006)\end{array}$ & $\begin{array}{c}-0.0038 \\
(0.003)\end{array}$ \\
\hline Non-categorical Income Limit X & & $0.0081^{* *}$ & 0.0002 & $0.0426 * * *$ \\
\hline
\end{tabular}


Notes: Sample is individual citizens ages 25 to 64 from 2011-2017 American Community Survey. Each cell is a coefficient on the state non-categorical income limit for the year prior to survey year from a separate regression. Unlike Tables 7 and 8, this analysis uses a two-way fixed effects specification without relying on border PUMAs. Analyses include PUMA fixed effects, year fixed effects, and controls for demographic group interacted with Black, demographic group interacted with Hispanic, female, age, age squared, education high school, education some college, and education college grad. Parental status defined by whether a parent reports a child in the household under 19 is their own biological, step, or adoptive child or that of their partner. The eligibility index has a mean (s.d.) of 1.76 (0.44); the enrollment index has a mean (s.d) of 2.20 (0.78); the unmet index has a mean (s.d.) of 0.14 (0.10). Robust standard errors clustered on state in parentheses. For coefficients, asterisks reflect p-values associated with the robust standard errors. ${ }^{* * *} \mathrm{p}<0.01, * * \mathrm{p}<0.05, * \mathrm{p}<0.1$. False discovery rate $\mathrm{q}$-values and associated asterisks are shown in brackets for interaction term coefficients. ${ }^{* * *} \mathrm{q}<0.01, * * \mathrm{q}<0.05, * \mathrm{q}<0.1$. 
Appendix Table 1: EITC Robustness

\begin{tabular}{|c|c|c|c|c|c|c|}
\hline & $\begin{array}{c}(1) \\
\text { EITC } \\
\text { Returns } \\
\text { Per 100 }\end{array}$ & $\begin{array}{c}(2) \\
\text { EITC } \\
\text { Returns } \\
\text { Per } 100\end{array}$ & $\begin{array}{c}(3) \\
\text { EITC } \\
\text { Returns } \\
\text { Per 100 }\end{array}$ & $\begin{array}{c}(4) \\
\text { EITC } \\
\text { Returns } \\
\text { Per } 100\end{array}$ & $\begin{array}{c}(5) \\
\text { EITC } \\
\text { Returns } \\
\text { Per } 100\end{array}$ & $\begin{array}{c}(6) \\
\text { EITC } \\
\text { Returns } \\
\text { Per 100 }\end{array}$ \\
\hline & $\begin{array}{c}\text { Minimal } \\
\text { Controls } \\
\text { (from Table 4) } \\
\end{array}$ & $\begin{array}{l}\text { Expanded } \\
\text { Controls }\end{array}$ & $\begin{array}{l}\text { Unemp } \\
\text { Control }\end{array}$ & $\begin{array}{l}\text { Minimal } \\
\text { Controls }\end{array}$ & $\begin{array}{l}\text { Expanded } \\
\text { Controls }\end{array}$ & $\begin{array}{l}\text { Unemp } \\
\text { Control }\end{array}$ \\
\hline $\begin{array}{l}\text { Non-categorical } \\
\text { Income Limit }\end{array}$ & $\begin{array}{c}0.088 \\
(0.053)\end{array}$ & $\begin{array}{c}0.071 \\
(0.052)\end{array}$ & $\begin{array}{c}0.068 \\
(0.052)\end{array}$ & & & \\
\hline Expansion Dummy & & & & $\begin{array}{c}0.050 \\
(0.079)\end{array}$ & $\begin{array}{c}0.035 \\
(0.075)\end{array}$ & $\begin{array}{c}0.031 \\
(0.075)\end{array}$ \\
\hline $\begin{array}{l}\text { Percent non-Hispanic } \\
\text { Black }\end{array}$ & $\begin{array}{c}0.266 * * * \\
(0.062)\end{array}$ & $\begin{array}{c}0.285^{* * *} \\
(0.052)\end{array}$ & $\begin{array}{c}0.294 * * * \\
(0.052)\end{array}$ & $\begin{array}{c}0.271^{* * *} \\
(0.064)\end{array}$ & $\begin{array}{c}0.289 * * * \\
(0.053)\end{array}$ & $\begin{array}{c}0.299 * * * \\
(0.052)\end{array}$ \\
\hline Percent Hispanic & $\begin{array}{l}0.154^{*} \\
(0.084)\end{array}$ & $\begin{array}{c}0.248 * * * \\
(0.074)\end{array}$ & $\begin{array}{c}0.242 * * * \\
(0.074)\end{array}$ & $\begin{array}{l}0.165^{*} \\
(0.086)\end{array}$ & $\begin{array}{c}0.260 * * * \\
(0.076)\end{array}$ & $\begin{array}{c}0.254^{* * *} \\
(0.077)\end{array}$ \\
\hline Percent Elderly & & $\begin{array}{c}0.271 * * * \\
(0.055)\end{array}$ & $\begin{array}{c}0.271^{* * *} \\
(0.056)\end{array}$ & & $\begin{array}{c}0.275 * * * \\
(0.055)\end{array}$ & $\begin{array}{c}0.275 * * * \\
(0.056)\end{array}$ \\
\hline $\begin{array}{l}\text { Unemployment } \\
\text { Rate }\end{array}$ & & & $\begin{array}{l}-0.044^{*} \\
(0.025)\end{array}$ & & & $\begin{array}{l}-0.045 * \\
(0.025)\end{array}$ \\
\hline $\begin{array}{l}\text { Observations } \\
\text { R-squared } \\
\text { County FE } \\
\text { County Pair*Year FE }\end{array}$ & $\begin{array}{l}16,730 \\
0.998 \\
\text { YES } \\
\text { YES }\end{array}$ & $\begin{array}{c}16,730 \\
0.998 \\
\text { YES } \\
\text { YES }\end{array}$ & $\begin{array}{c}16,730 \\
0.998 \\
\text { YES } \\
\text { YES }\end{array}$ & $\begin{array}{c}16,730 \\
0.998 \\
\text { YES } \\
\text { YES }\end{array}$ & $\begin{array}{c}16,730 \\
0.998 \\
\text { YES } \\
\text { YES }\end{array}$ & $\begin{array}{c}16,730 \\
0.998 \\
\text { YES } \\
\text { YES }\end{array}$ \\
\hline
\end{tabular}

Estimates are weighted by working age population or total population. Robust standard errors clustered on state in parentheses. ${ }^{* * *}$ $\mathrm{p}<0.01, * * \mathrm{p}<0.05, * \mathrm{p}<0.1$ 
Appendix Table 2: SNAP Robustness

\begin{tabular}{|c|c|c|c|c|c|c|}
\hline & $\begin{array}{c}\text { (1) } \\
\text { SNAP } \\
\text { Participation } \\
\text { Rate }\end{array}$ & $\begin{array}{c}\text { (2) } \\
\text { SNAP } \\
\text { Participation } \\
\text { Rate }\end{array}$ & $\begin{array}{c}\text { (3) } \\
\text { SNAP } \\
\text { Participation } \\
\text { Rate }\end{array}$ & $\begin{array}{c}\text { (4) } \\
\text { SNAP } \\
\text { Participation } \\
\text { Rate }\end{array}$ & $\begin{array}{c}(5) \\
\text { SNAP } \\
\text { Participation } \\
\text { Rate }\end{array}$ & $\begin{array}{c}\text { (6) } \\
\text { SNAP } \\
\text { Participation } \\
\text { Rate }\end{array}$ \\
\hline & $\begin{array}{c}\text { Minimal } \\
\text { Controls } \\
\text { (from Table 5) }\end{array}$ & $\begin{array}{l}\text { Expanded } \\
\text { Controls }\end{array}$ & $\begin{array}{l}\text { Unemp } \\
\text { Control }\end{array}$ & $\begin{array}{l}\text { Minimal } \\
\text { Controls }\end{array}$ & $\begin{array}{l}\text { Expanded } \\
\text { Controls }\end{array}$ & $\begin{array}{l}\text { Unemp } \\
\text { Control }\end{array}$ \\
\hline $\begin{array}{l}\text { Non-categorical } \\
\text { Income Limit }\end{array}$ & $\begin{array}{l}0.433^{* *} \\
(0.189)\end{array}$ & $\begin{array}{l}0.416 * * \\
(0.176)\end{array}$ & $\begin{array}{c}0.432 * * * \\
(0.152)\end{array}$ & & & \\
\hline Expansion Dummy & & & & $\begin{array}{c}0.596 * * * \\
(0.207)\end{array}$ & $\begin{array}{c}0.558 * * * \\
(0.203)\end{array}$ & $\begin{array}{c}0.573 * * * \\
(0.181)\end{array}$ \\
\hline $\begin{array}{l}\text { Percent non-Hispanic } \\
\text { Black }\end{array}$ & $\begin{array}{c}0.776 * * * \\
(0.230)\end{array}$ & $\begin{array}{c}0.803 * * * \\
(0.244)\end{array}$ & $\begin{array}{l}0.723 * * \\
(0.264)\end{array}$ & $\begin{array}{c}0.782 * * * \\
(0.233)\end{array}$ & $\begin{array}{c}0.808 * * * \\
(0.250)\end{array}$ & $\begin{array}{l}0.728 * * \\
(0.271)\end{array}$ \\
\hline Percent Hispanic & $\begin{array}{c}0.453 \\
(0.372)\end{array}$ & $\begin{array}{c}0.383 \\
(0.354)\end{array}$ & $\begin{array}{c}0.352 \\
(0.293)\end{array}$ & $\begin{array}{c}0.459 \\
(0.378)\end{array}$ & $\begin{array}{c}0.396 \\
(0.366)\end{array}$ & $\begin{array}{c}0.367 \\
(0.300)\end{array}$ \\
\hline Percent Elderly & & $\begin{array}{l}-0.193 \\
(0.364)\end{array}$ & $\begin{array}{l}-0.204 \\
(0.379)\end{array}$ & & $\begin{array}{l}-0.190 \\
(0.366)\end{array}$ & $\begin{array}{l}-0.200 \\
(0.380)\end{array}$ \\
\hline ABAWD Waiver & & $\begin{array}{c}0.463 \\
(0.374)\end{array}$ & $\begin{array}{c}0.438 \\
(0.377)\end{array}$ & & $\begin{array}{c}0.433 \\
(0.375)\end{array}$ & $\begin{array}{c}0.409 \\
(0.380)\end{array}$ \\
\hline $\begin{array}{l}\text { Unemployment } \\
\text { Rate }\end{array}$ & & & $\begin{array}{c}0.367 * * \\
(0.173)\end{array}$ & & & $\begin{array}{c}0.366^{* * *} \\
(0.175)\end{array}$ \\
\hline Observations & 12,197 & 12,197 & 12,197 & 12,197 & 12,197 & 12,197 \\
\hline R-squared & 0.990 & 0.990 & 0.990 & 0.990 & 0.990 & 0.990 \\
\hline County FE & YES & YES & YES & YES & YES & YES \\
\hline County Pair*Year FE & YES & YES & YES & YES & YES & YES \\
\hline
\end{tabular}

Estimates are weighted by working age population or total population. Robust standard errors clustered on state in parentheses. $\mathrm{p}<0.01,{ }^{* *} \mathrm{p}<0.05, * \mathrm{p}<0.1$ 


\section{Appendix Table 3. Weighted Baseline Means of ACS Outcome Variables in 2011 ACS, by Demographic Group}

\begin{tabular}{|c|c|c|c|c|}
\hline $\begin{array}{c}\text { All } \\
(\mathrm{N}=20,267,758)\end{array}$ & $\begin{array}{c}\text { Non-Parents }<50 \\
(\mathrm{~N}=4,732,326)\end{array}$ & $\begin{array}{c}\text { Non-Parents } \\
50+ \\
(\mathrm{N}=8,127,240)\end{array}$ & $\begin{array}{l}\text { Single Parents } \\
(\mathrm{N}=1,652,339)\end{array}$ & $\begin{array}{c}\text { Married Parents } \\
(\mathrm{N}=5,755,853)\end{array}$ \\
\hline
\end{tabular}

Any Health Insurance

0.83

Any Health Insurance $<130$ Percent of Poverty

Public Health Ins

Private Health Ins

Any SNAP

Any SNAP $<130$ Percent of Poverty

SNAP \& Public Health Ins

SNAP \& No Public Health Ins

No SNAP \& Public Health Ins

Any TANF

Imputed EITC Eligibility

Under 130 Percent of Poverty

Under 50 Percent of Poverty

Any Earnings

Any Wages

Any Business Income

Any Usual Hours Worked

Full-time Hours

Number Earners (Self and/or Spouse)

Any Earners (Self or Spouse)

Any Wages (Self or Spouse)

Any Business Income (Self or Spouse)

Log(Combined Earnings)
0.62

0.15

0.72

0.14

0.44

0.07

0.08

0.08

0.02

0.15

0.23

0.09

0.78

0.73

0.07

0.78

0.64

1.24

0.86

0.82

0.11

10.76
0.74

0.50

0.12

0.64

0.15

0.38

0.06

0.10

0.07

0.02

0.12

0.27

0.13

0.82

0.78

0.06

0.82

0.68

1.08

0.85

0.81

0.08

10.46
0.87

0.67

0.18

0.75

0.11

0.39

0.06

0.05

0.12

0.01

0.05

0.17

0.06

0.68

0.63

0.08

0.69

0.55

1.12

0.78

0.74

0.12

10.76
0.74

0.65

0.28

0.49

0.40

0.63

0.21

0.19

0.07

0.06

0.44

0.51

0.24

0.79

0.75

0.05

0.79

0.62

0.79

0.79

0.75

0.05

10.00
0.90

0.71

0.09

0.84

0.09

0.40

0.05

0.05

0.05

0.01

0.20

0.17

0.04

0.85

0.80

0.08

0.85

0.71

1.69

0.98

0.96

0.15

11.21 